\title{
Review \\ An Overview on Anodes for Magnesium Batteries: Challenges towards a Promising Storage Solution for Renewables
}

\author{
Federico Bella *D, Stefano De Luca, Lucia Fagiolari $(D)$, Daniele Versaci $\mathbb{D}$, Julia Amici, Carlotta Francia \\ and Silvia Bodoardo
}

check for

updates

Citation: Bella, F.; De Luca, S.; Fagiolari, L.; Versaci, D.; Amici, J.; Francia, C.; Bodoardo, S. An Overview on Anodes for Magnesium Batteries: Challenges towards a Promising Storage Solution for Renewables. Nanomaterials 2021, 11, 810. https://doi.org/10.3390/ nano11030810

Academic Editor: Sonia Dsoke

Received: 25 February 2021

Accepted: 17 March 2021

Published: 22 March 2021

Publisher's Note: MDPI stays neutral with regard to jurisdictional claims in published maps and institutional affiliations.

Copyright: (C) 2021 by the authors. Licensee MDPI, Basel, Switzerland. This article is an open access article distributed under the terms and conditions of the Creative Commons Attribution (CC BY) license (https:/ / creativecommons.org/licenses/by/ $4.0 /)$.
Department of Applied Science and Technology, Politecnico di Torino, Corso Duca degli Abruzzi 24, 10129 Turin, Italy; s269980@studenti.polito.it (S.D.L.); lucia.fagiolari@polito.it (L.F.); daniele.versaci@polito.it (D.V.); julia.amici@polito.it (J.A.); carlotta.francia@polito.it (C.F.); silvia.bodoardo@polito.it (S.B.)

* Correspondence: federico.bella@polito.it

\begin{abstract}
Magnesium-based batteries represent one of the successfully emerging electrochemical energy storage chemistries, mainly due to the high theoretical volumetric capacity of metallic magnesium (i.e., $3833 \mathrm{mAh} \mathrm{cm}^{-3}$ vs. $2046 \mathrm{mAh} \mathrm{cm}^{-3}$ for lithium), its low reduction potential (-2.37 V vs. SHE), abundance in the Earth's crust $\left(10^{4}\right.$ times higher than that of lithium) and dendrite-free behaviour when used as an anode during cycling. However, $\mathrm{Mg}$ deposition and dissolution processes in polar organic electrolytes lead to the formation of a passivation film bearing an insulating effect towards $\mathrm{Mg}^{2+}$ ions. Several strategies to overcome this drawback have been recently proposed, keeping as a main goal that of reducing the formation of such passivation layers and improving the magnesium-related kinetics. This manuscript offers a literature analysis on this topic, starting with a rapid overview on magnesium batteries as a feasible strategy for storing electricity coming from renewables, and then addressing the most relevant outcomes in the field of anodic materials (i.e., metallic magnesium, bismuth-, titanium- and tin-based electrodes, biphasic alloys, nanostructured metal oxides, boron clusters, graphene-based electrodes, etc.).
\end{abstract}

Keywords: magnesium battery; anode; Sn-Bi alloy; post-Li battery; Mg metal

\section{Introduction}

The high concentration of $\mathrm{CO}_{2}$ in the atmosphere is causing a temperature rise never recorded before, due to its strong greenhouse effect [1-3]. This problem arises from decades of increased use of fossil fuels for energy purposes, with tons of $\mathrm{CO}_{2}$ consequentially released into the atmosphere, formed by carbon atoms which were previously stocked underground [4-6]. Even today, most of the energy is generated from fossil sources [7-9]. Furthermore, due to the demographic and/or economic growth of some areas of the world, it is expected that by 50 years the energy consumption is destined to double [10]. In a similar framework, action must be taken immediately and effectively to prevent an uncontrolled increase of the average temperature of the planet. Fossil fuels must be replaced by clean energy sources, which does not involve greenhouse gas emissions, and a significant amount of attention is paid towards renewable energy solutions. However, renewable energies have a major disadvantage, which greatly limits their diffusion, i.e., their poor predictability [11,12]. It may, therefore, happen that, when the energy demand is high, production through renewables is weak, or that there is a surplus of production at times with low demand. Moreover, it is possible that consumption by users of an electricity grid based on photovoltaic energy mainly occurs after sunset $[13,14]$.

In this scenario, California could represent a case study, being a state historically launched towards a wide use of renewable energy sources, photovoltaics in particular [15-19]; the above-mentioned issues were highlighted some years ago [20-22]. In the chart shown in Figure $1 \mathrm{~A}$, it is possible to appreciate the difference between the demand for electricity and 
the electric power produced by photovoltaic panels in the Californian grid, in a typical spring day and depending on the various years from 2012 to 2020 [23,24]. An approximatively constant delta is observed in the early hours of the morning, which then decreases as sun rises and photovoltaic production begins. This tendency is increasingly emphasized as years pass, until the spread undergoes a real collapse moving towards 2020. In the central hours of the day, there is even an over-generation risk, as photovoltaic power rapidly increases and sums to the other means of production already in action, with the consequence that the instantaneously generated energy might be higher than the demand, which is highly dangerous for the electricity grid. In the final hours of the day, the tendency is reversed: in a very short time, the demand for electricity goes up, while photovoltaic panels stop producing, so that just where a peak of the demand is observed it is no longer possible to rely on solar energy. Due to the shape composed by the curves, which resemble a duck, this graph has been called the "duck curve" [25,26], and highlights a problem that actually goes beyond the borders of California.
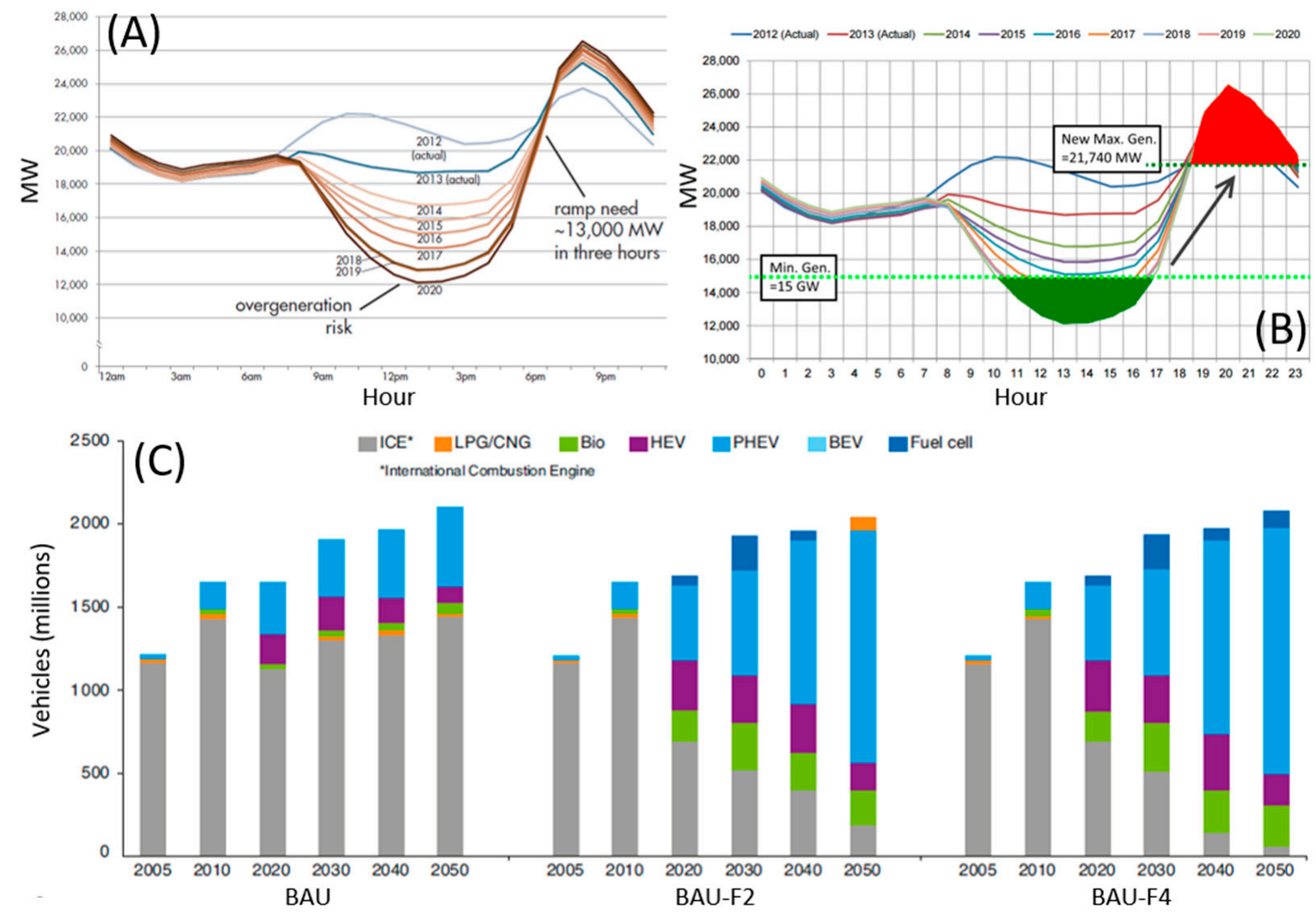

Figure 1. (A) Difference between electricity demand and photovoltaic electricity produced during a typical spring day and in different years in the Californian grid; (B) "Duck curve" showing energy storage to capture energy during overgeneration risk period (green area) and discharging said energy during peak net load hours (red area); (C) Evolution scenarios of the global car fleet, including combustion vehicles (ICE), liquefied or compressed natural gas (LPG/CNG), hybrid (HEV), plugin hybrid (PHEV), electric with batteries (BEV), electric with fuel cells (Fuel cell). Adapted with permission from [27-29]. Copyright California ISO (2013), Stanford University (2015) and IFP Energies Nouvelles (2018).

Similar problems are common to other kinds of renewable energies [30-34]. It is, therefore, clear that, in order to reach a correct integration of renewables, a way to store energy when in excess and to use it when needed is necessary [35-39]. Still referring to the "duck curve", a significant step forward in terms of efficiency and reduction of $\mathrm{CO}_{2}$ emissions would be made if the excess of photovoltaic electricity produced in the middle of the day was stored and used after the sunset, concurring to satisfy the high demand of 
the evening and avoiding the over-generation risks [40-44]. This is what is highlighted in the graph shown in Figure 1B.

Rechargeable batteries, being devices capable of reversibly converting electricity into chemical energy, stand among the most suitable technologies to accomplish this task [45-49]. Their use is not limited to the purposes highlighted above, but is destined to become increasingly massive also in the automobile industry [50-54]. The number of hybrid or electric cars produced is getting bigger and bigger [55-57]. In Figure 1C, the evolution of the global car fleet is quantified, according to three different scenarios. BAU stands for "business as usual" and represents an extension of the current trend over time. "BAU-F2" and "BAU-F4" represent scenarios in which the $\mathrm{CO}_{2}$ emissions of the transport sector are divided by 2 and by 4 compared to 2005, respectively. It is, therefore, clear that the role of transport electrification will be fundamental in order to reduce the emissions [29].

To date, a large number of rechargeable batteries exists, bearing different characteristics, uses, advantages and disadvantages. Some of the most important are classified in Table 1 [10].

Table 1. Main battery technologies, along with typical electrochemical performance, application and constrains. Adapted with permission from [10]. Copyright Elsevier B.V., 2014.

\begin{tabular}{|c|c|c|c|c|}
\hline Battery Type & $\begin{array}{c}\text { Specific } \\
\text { Energy-Gravimetric } \\
\left(\mathrm{Wh} \mathrm{kg}^{-1}\right)\end{array}$ & $\begin{array}{l}\text { Cycle Life } \\
\text { (Lifetime) }\end{array}$ & Advantages & Technical and Cost Barriers \\
\hline Lead acid [58] & $30-50$ & $500-1000$ & $\begin{array}{l}\text { Low cost, mature and readily } \\
\text { available, reliable and easily } \\
\text { replaced, suitable for power } \\
\text { quality, UPS and spinning } \\
\text { reserve applications. }\end{array}$ & $\begin{array}{l}\text { Short cycling capability, low power } \\
\text { and energy density, slow charge. } \\
\text { Low weight-to-energy ratio, } \\
\text { thermal management requirement, } \\
\text { environmental hazards, but fully } \\
\text { recyclable. }\end{array}$ \\
\hline Ni-Cd sealed [59] & $30-45$ & $500-800$ & $\begin{array}{l}\text { Relatively high energy density, } \\
\text { relatively low cycling capability, } \\
\text { high mechanical resistance, low } \\
\text { maintenance requirement, } \\
\text { suitable for power tools, } \\
\text { emergency lighting, generator } \\
\text { starting, telecoms and } \\
\text { portable devices. }\end{array}$ & $\begin{array}{l}\text { High cost, environmental hazards, } \\
\text { memory effect. }\end{array}$ \\
\hline Ni-MH [59] & $40-80$ & $600-1200$ & $\begin{array}{l}\text { Hybrid electric vehicles, portable } \\
\text { electronic devices. }\end{array}$ & $\begin{array}{l}\text { High self-discharge rate, } \\
\text { low-temperature performance of } \\
\text { the metal-hydride anode. }\end{array}$ \\
\hline Na-S [58] & $150-240$ & 2500 & $\begin{array}{l}\text { Relatively high power and } \\
\text { energy density, efficient, } \\
\text { economical for power quality } \\
\text { and peak shaving purposes. }\end{array}$ & $\begin{array}{l}\text { High operating temperature } \\
\left(\approx 300-350^{\circ} \mathrm{C}\right) . \text { Heat source } \\
\text { requirement, high cost. }\end{array}$ \\
\hline NaNiCl ZEBRA [59] & $85-140$ & $\approx 2500$ & $\begin{array}{l}\text { Ability to withstand limited } \\
\text { overcharge and discharge, } \\
\text { relatively high electrochemical } \\
\text { cell voltage }(2.58 \mathrm{~V}) \text {, suitable for } \\
\text { load-levelling applications }\end{array}$ & $\begin{array}{l}\text { High operating temperature } \\
\left(\approx 270-350{ }^{\circ} \mathrm{C}\right) \text {, limited energy } \\
\text { density. Lower power and energy } \\
\text { density compared to NaS. }\end{array}$ \\
\hline $\begin{array}{l}\text { Vanadium redox flow } \\
\text { battery [58] }\end{array}$ & $10-30$ & 12,000 & $\begin{array}{c}\text { Energy and power independent, } \\
\text { long life cycle, low self-discharge } \\
\text { rates. Useful for } \\
\text { large-scale applications. }\end{array}$ & $\begin{array}{l}\text { High cost, complex } \\
\text { standardization, low energy and } \\
\text { power density, toxic remains. }\end{array}$ \\
\hline Lithium ion $[10,59,60]$ & $100-300$ & $>5000$ & $\begin{array}{l}\text { Relatively high power and } \\
\text { density, almost } 100 \% \text { efficient, } \\
\text { higher cycling capacity, fast } \\
\text { response to charge and } \\
\text { discharge operations. Useful for } \\
\text { laptop computers, mobile } \\
\text { devices, hybrid electric vehicles. }\end{array}$ & $\begin{array}{l}\text { Reduced first-cycle capacity loss } \\
\text { and volumetric expansion of } \\
\text { intermetallic electrodes. High cost, } \\
\text { degrades at high temperatures. }\end{array}$ \\
\hline
\end{tabular}


However, all the batteries listed above are far from allowing the existence of a society based on renewable sources, where a large amount of energy is stored for residential and transport sectors. Depending on the type, there are disadvantages linked to efficiency, cost, toxicity or safety, which severely limit a mass use as needed [10].

Among all types of batteries, lithium-ion batteries (LIBs) play a crucial role in the evolution of modern technologies [61-65]: they are used in laptops, cell phones, electric vehicles and many other devices [66-70]. Made with graphitized carbon as anode material and a transition metal oxide as cathode, they are able to accumulate $240 \mathrm{Wh} \mathrm{kg}^{-1}$ or $640 \mathrm{Wh} \mathrm{L}^{-1}$ for thousands of cycles [71]. They will probably drive technological progress for many other years, as no better batteries (in terms of energy density and lightweight) will be available in the near future. The LIB, however, possesses multiple drawbacks [72-76]. One of the main limitations is the relatively scarce concentration of lithium in the Earth's crust $[77,78]$, that in addition is mostly located in a few countries (Bolivia and Chile owe more than $50 \%$ of global resources, as depicted in Figure 2). Difficulties with current technology in disposing the exhausted LIBs and in recovering lithium from them at reasonable prices make the situation worse [79-81]. Production cost, despite all the progresses made, is still quite high, and also represents an obstacle. Finally, there are problems related to safety of use of the battery: over time, the anode degrades giving rise to dendritic formations that may lead to short circuits, overheating and possible battery explosion [10,82-85].

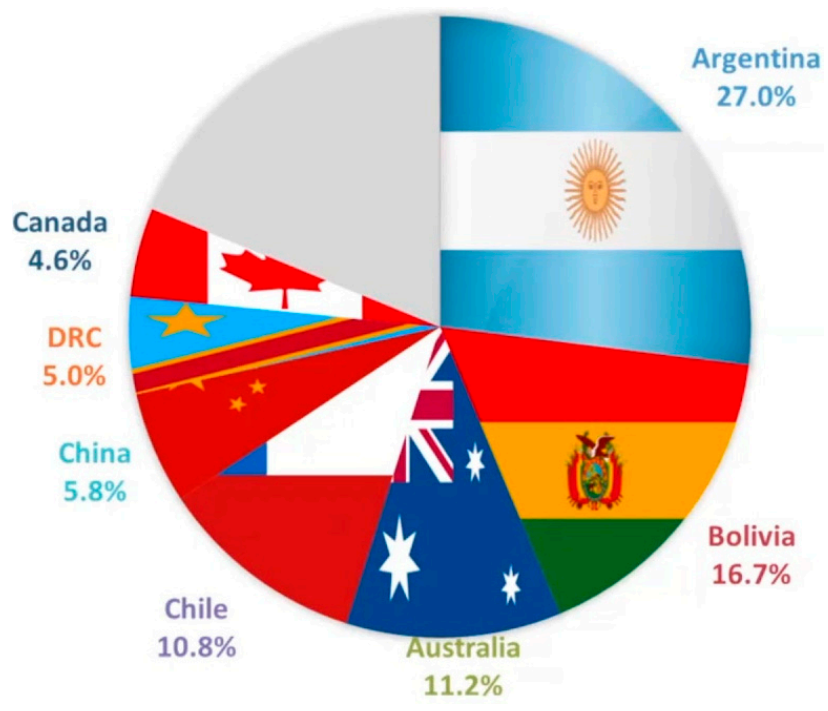

Figure 2. Distribution of lithium resources in 2019. Adapted with permission from [86]. Copyright Edison, 2019.

Given all the reasons mentioned above, scientists are looking for new types of batteries (the so-called "new chemistries" [87-91]). One of the most interesting solutions seems to be represented by the rechargeable magnesium-ion batteries (MIBs) [92-96], which utilize magnesium cations as the active charge transporting species in solution and (in many cases) metallic magnesium as the anode. A primary advantage of this technology is given by the solid magnesium anode that leads to high energy density values, well above those of lithium-based cells [97-101]. However, some issues have emerged when using elemental magnesium and novel solutions have been proposed. In this mini review, we will highlight the current pros and cons of MIBs, with a special focus on the role of metallic magnesium anodes and the most reliable alternatives when the upscaling of this technology (e.g., for large-scale energy storage coupled with renewables) is conceived. In addition, the nanodimensionality of the proposed anodic materials and its effect on the electrochemical behaviour of the resulting MIBs will be highlighted, by discussing case studies based on nanotubes, nanoparticles, nanopores, nanocrystals, nanoflakes and nanowires. 


\section{Rechargeable Magnesium-Ion Batteries: State of Art}

With reference to the scheme shown in Figure 3, the MIB device is not different with respect to the corresponding lithium or sodium counterparts. Magnesium metal has huge potentialities to serve as an anode material for rechargeable batteries, starting from its theoretical volumetric capacity of $3832 \mathrm{mAh} \mathrm{cm}^{-3}$, clearly superior to that of metallic lithium $\left(2061 \mathrm{mAh} \mathrm{cm}^{-3}\right)$ [102]. Moreover, although lithium has a higher mass capacity, the chemistry of magnesium does not lead to dendrite formation, considerably improving the safety of devices where these batteries are used [103]. The greatest advantage of magnesium lies on its abundance, being one of the most abundant elements in the Earth's crust. This would benefit production costs and availability of the supply, because the extraction of magnesium cannot risk being monopolized by a small number of countries as in the case of lithium, and because it is possible to rely on larger amount of raw material. Table 2 shows the average abundance, expressed in ppm, of some elements in the Earth's crust; the comparison between lithium and magnesium is noteworthy [104].

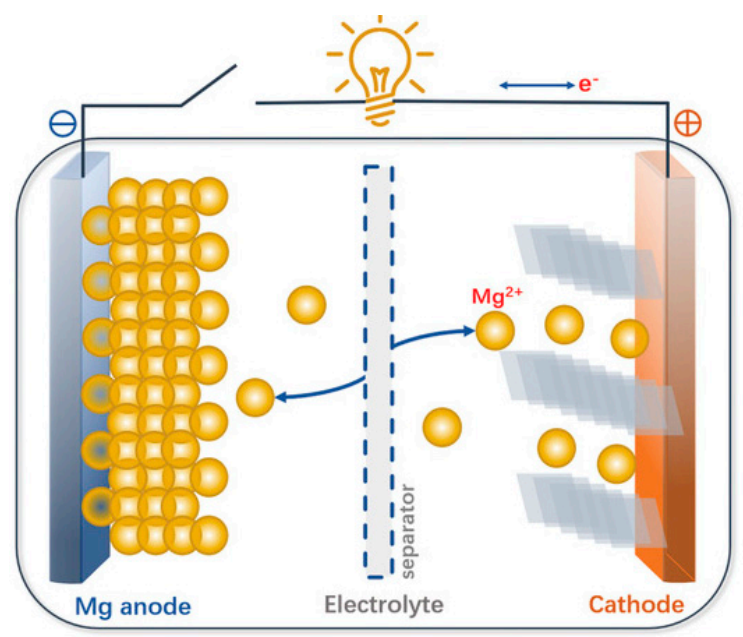

Figure 3. Scheme and working principle of a magnesium rechargeable battery. Adapted with permission from [105]. Copyright John Wiley \& Sons, Inc., 2020.

Table 2. Average abundancy in the Earth's crust of the most commonly used elements in the batteries field. Adapted with permission from [106]. Copyright John Wiley \& Sons, Inc., 1983.

\begin{tabular}{cccc}
\hline Element & $\begin{array}{c}\text { Average Abundancy } \\
(\mathbf{p p m})\end{array}$ & Element & $\begin{array}{c}\text { Average Abundancy } \\
\text { (ppm) }\end{array}$ \\
\hline Aluminium & 84,249 & Sulphur & 404 \\
\hline Iron & 52,157 & Chromium & 320 \\
\hline Magnesium & 28,104 & Zinc & 72 \\
\hline Sodium & 22,774 & Copper & 27 \\
\hline Titanium & 4136 & Cobalt & 26.6 \\
\hline Manganese & 774 & Nickel & 26.6 \\
\hline Phosphorus & 567 & Lanthanum & 20 \\
\hline Barium & 456 & Lithium & 16 \\
\hline
\end{tabular}

Moreover, another advantage, considering a future battery industry and the entire supply chain, of magnesium versus lithium is its perfect recyclability. In fact, with respect to other metals, magnesium can be recycled without any degradation of its physical properties. The energy cost for recycling and melting processes is also lower than that required for recycling other metals and is approximately $5 \%$ of the cost required for the production of crude $[107,108]$, and better performances of recycling are achieved. This is also clear from 
Figure 4, that shows the end-of-life recycling rate of some elements of the periodic table, i.e., the ratio between the amount of element truly recycled and the total quantity of element introduced in the recycling flow (noteworthy comparing the $25-50 \%$ of magnesium vs. less than $1 \%$ for lithium).

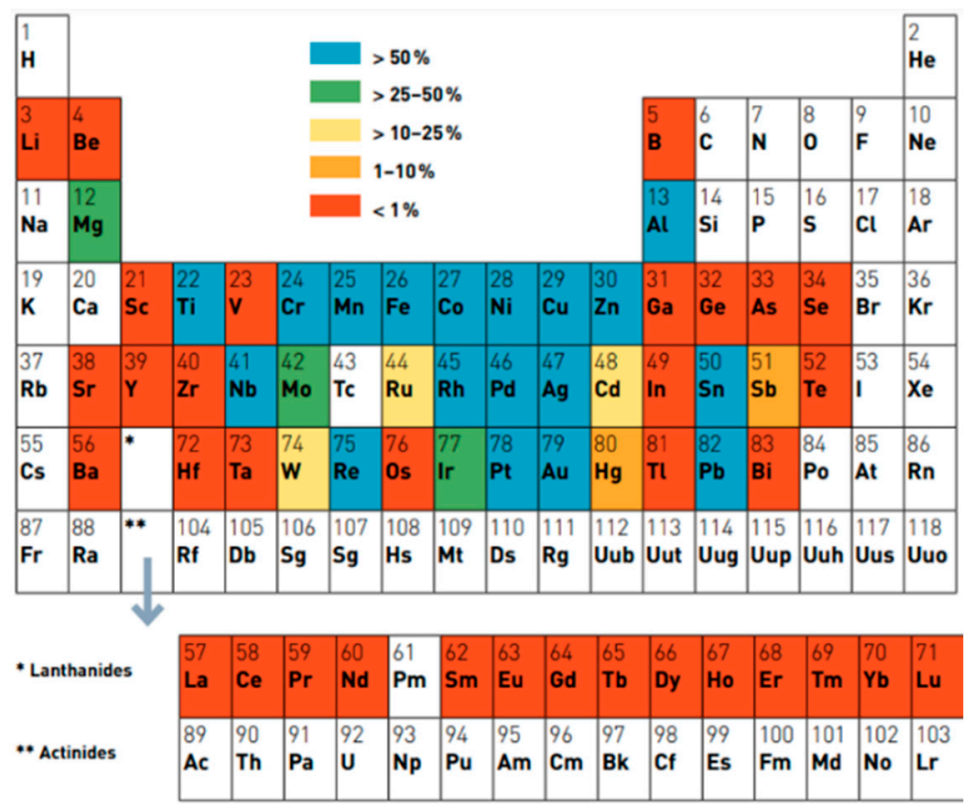

Figure 4. End-of-life recycling rate of some elements of the periodic table. Adapted with permission from [109]. Copyright UNEP, 2011.

Despite these advantages, turning MIBs into a marketable solution is not trivial at all, due to several technical challenges. The biggest problem is the strong tendency of magnesium to passivate in a wide variety of solvents, salts and contaminants, so that any kind of electrochemical reaction is blocked and magnesium deposition/dissolution process is not reversible. Another major challenge consists in coupling $\mathrm{Mg}$ with a highvoltage/high-capacity cathode in which the anode can behave reversibly. Many cathodic materials, capable to reversibly store lithium ions, do not work with magnesium ions, mainly because of their high charge density, caused by the divalent character of the ions, with a small radius, leading to strong and detrimental interactions with the host material. These two problems are enough to dramatically reduce the number of available electrolytes and cathodes, making the research extremely difficult [110].

According to the current state-of-the-art MIB components [105,111-114], the anode may be realized using magnesium metal or some alternative materials. Among those, some of the most studied and promising are bismuth and tin. As for the cathode, four of the most important families have been identified: cobalt, vanadium, molybdenum and manganese-based cathodes [110,115-118]. It is of primary importance, for a good cathode, to reversibly host magnesium ions and allow their high mobility within the electrode matrix, assuring the anode compatibility with the electrolyte. Solutions based on Grignard reagents, organoborate, borohydride and $\mathrm{Mg}(\mathrm{TFSI})_{2}$ are some of the most studied electrolytes [119-122]. Important parameters that guide the electrolyte selection are the resistance to oxidation, the Coulombic efficiency (i.e., a measure of the reversibility of charge deposition), fast charge transport, the behaviour in the presence of contaminants and the volatility. Innovative solutions such as solid magnesium electrolytes have also been proposed, aiming at overcoming the issue of volatility, while keeping possible a good charge transport [71]. 


\section{Magnesium Metal as Anode}

As said, magnesium possesses very interesting properties. On one hand, it is theoretically capable of storing up to $3832 \mathrm{mAh} \mathrm{cm}^{-3}$ of charge [102], and its high reactivity imparts to the metal with the desired virtue of a significantly negative voltage. Even though the nature of the passivating layer has not been fully understood, it is known that its formation comes from the high reactivity of magnesium metal, which acts as a double-edged sword: electrolytes are instable in proximity of the anode and their decomposition occurs [123]. The passivating nature of this layer contrasts with what is observed when analogous electrolytes are in contact with lithium metal [124-128]. In this case, the formation of the layer, the solid electrolyte interphase (SEI), allows the diffusion of lithium ions and prevents further decomposition of the electrolyte in the highly reducing environment during lithium plating [129-133].

The research on suitable electrolytes is not a simple task, and hampers the overall development of the battery [134-138]. As depicted in Figure 5, electrolytes based on magnesium salts, for example perchlorates and tetrafluroborates, and polar aprotic solvents, like carbonates and nitriles, form a passivating layer [103]. This explains why the choice of the electrolyte is limited to a few possibilities. An example is given by Grignard-based electrolyte solutions, that, however, suffer of limited anodic stability $[139,140]$.

(A)

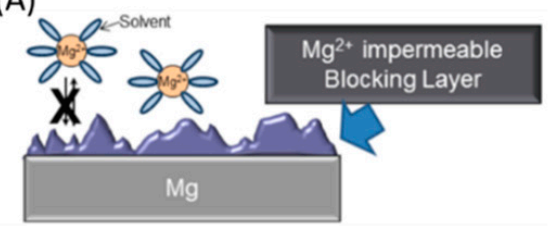

(B)

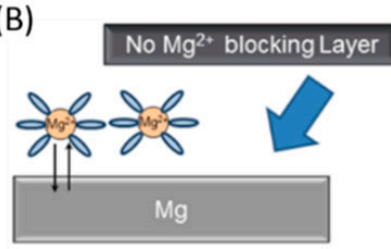

(C)

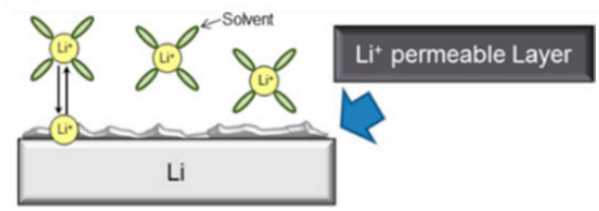

Figure 5. The metal/electrolyte interfaces for (A,B) magnesium- and (C) lithium-based systems. Different from lithium, magnesium experiences passivation when the metal is exposed to conventional electrolytes (case A, e.g., with ionic salts and polar solvents), while magnesium passivation does not occur in ethereal organo-magnesium electrolytes (case B, e.g., with Grignard-based solutions). Adapted with permission from [71]. Copyright Beilstein-Institut, 2014.

Anyway, an important advantage of magnesium anode is related to the morphology of magnesium deposits. Unlike lithium [141-145], plating magnesium from organohaloaluminate electrolyte does not involve dendrites formation. Moreover, the morphology of magnesium deposits from magnesium aluminate complexes has been related to the current densities applied during deposition. No dendritic formations have been observed, but, as shown in Figure 6, there is a preferred orientation of the deposits, depending on the current density. For instance, (001) orientation is the preferred one at low current densities, while the (100) is preferred at high current densities. Consequently, it is possible to hypothesize that both thermodynamic stability and diffusion rates of $\mathrm{Mg}$ ions govern the crystals growth of magnesium depositions [71,146].

It is expected that advancements in the understanding of magnesium chemistry will lead to the achievement of advanced SEI layers, similar to those formed in traditional LIBs [147-151]. To date, it is of crucial importance that the anode remains free from any solid passivation layer in order to allow reversible stripping/plating. Thus, only chemically stable electrolytes are viable in batteries that use such anode materials. Furthermore, a selection has to be made, as many compatible electrolytes cannot be used in practical systems due to issues of safety, low electrochemical stability window and high cost. 

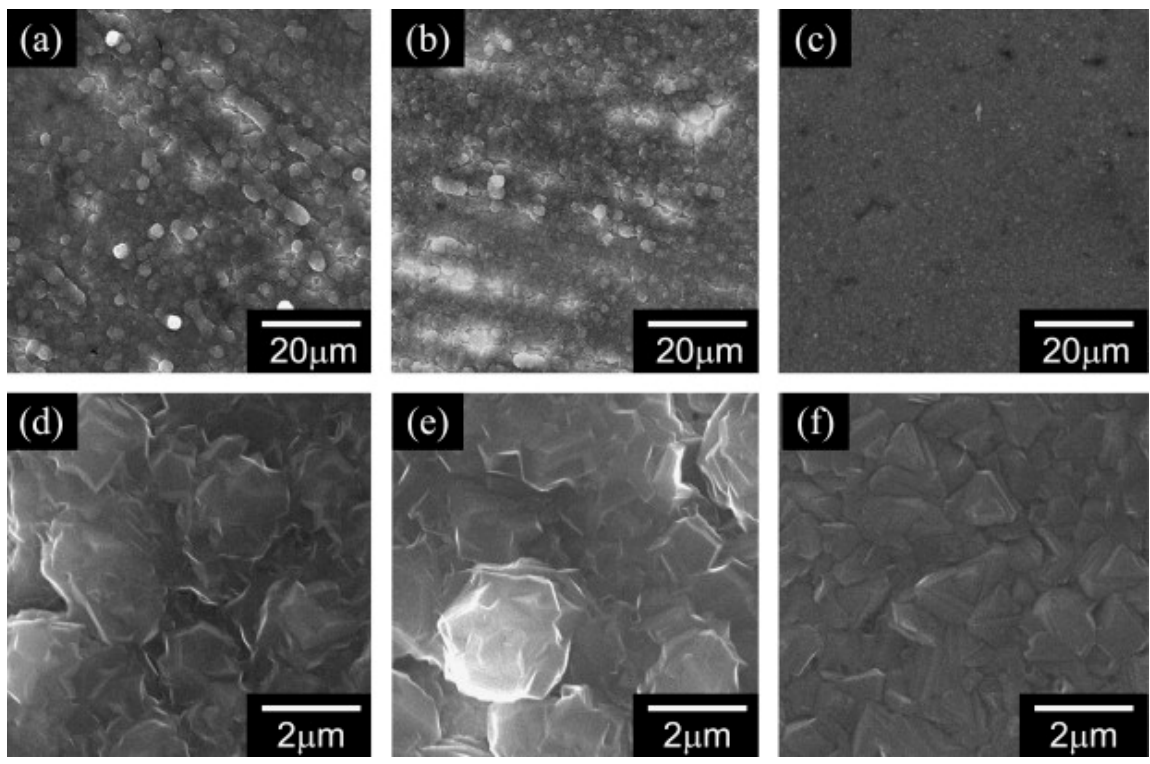

Figure 6. Scanning electron microscopy (SEM) micrographs of electrodeposited magnesium at different current densities: (a) $0.5 \mathrm{~mA} \mathrm{~cm}^{-2}$; (b) $1.0 \mathrm{~mA} \mathrm{~cm}^{-2}$; (c) $2.0 \mathrm{~mA} \mathrm{~cm}^{-2}$; (d) $0.5 \mathrm{~mA} \mathrm{~cm}^{-2}$; (e) $1.0 \mathrm{~mA} \mathrm{~cm}^{-2}$ and (f) $2.0 \mathrm{~mA} \mathrm{~cm}^{-2}$. Adapted with permission from [146]. Copyright Elsevier B.V., 2011.

Compatibility among magnesium anode, electrolyte and cathode should also be taken into account. At first, a large part of the electrolyte solutions that allowed reversible magnesium deposition had a very low anodic stability window, with a maximum of 2-2.4 V vs. $\mathrm{Mg}^{2+} / \mathrm{Mg}$. This narrow voltage limitation is not acceptable with high-voltage metal oxide cathodes. Recently, electrolyte formulation without Grignard reagents, which are able to reach the anodic stability up to $3.3 \mathrm{~V}$, have been proposed. Nonetheless, most of them contain chlorides, which may be corrosive to metal oxide cathode materials and current collectors [110]. In addition, 1,2-dimethoxyethane (DME)—an important solvent in nonaqueous electrolytic solutions-hinders intercalation of magnesium ions into $\mathrm{V}_{2} \mathrm{O}_{5}$ [152] cathode material.

\section{Strategies beyond Elemental Magnesium Anodes}

The use of alternative anodic materials has been recently proposed, so that conventional electrolytes may be employed [153-157]. These are magnesium ion insertion anodes, composed by an alloy of magnesium combined with other metals. The principle behind this choice is that magnesium alloys, if thermodynamically favourable, should lower the reductive power of the anode. As a consequence, such materials will have less negative potential, that may lead to anodes chemically consistent with electrolytes and some contaminants too. As a result, a wide variety of electrolytes would be available for reversible magnesium alloying-dealloying reactions. To this purpose, new materials should satisfy some requirements, that can be summarized as follows:

- Cheap, ubiquitous, eco-friendly and safe materials;

- Highly reversible alloying-dealloying process;

- Sufficiently fast magnesium diffusion, or phase propagation, within the base metal;

- High energy density;

- The voltage difference between alloying-dealloying processes must be as small as possible;

- Compatibility with inert components, such as conducting additives, binders and current collectors must be assured.

Despite these drawbacks, the possible electrode pulverization, as consequence of volume changes, and sluggish magnesium insertion/extraction kinetics, insertion anodes are gaining interest as alternatives to magnesium metal $[71,110]$. 


\subsection{Bismuth-Based Anodes}

Bismuth-based anodes are among the most studied alternative anodes, due to the rhombohedral crystalline structure of bismuth that allows formation of alloys with high volumetric capacity [158]. The gravimetric capacity theoretically achievable is also high, about $385 \mathrm{mAh} \mathrm{g}^{-1}$, hypothesizing the transfer of six electrons and the formation of the alloy according to the following reaction [159]:

$$
2 \mathrm{Bi}+3 \mathrm{Mg}^{2+}+6 \mathrm{e}^{-} \rightarrow \mathrm{Mg}_{3} \mathrm{Bi}_{2}
$$

An interesting superionic conductivity of magnesium ions in $\beta-\mathrm{Mg}_{3} \mathrm{Bi}_{2}$ has been shown [160]. The electrochemical behaviour of this alloy and some of its derivatives was studied by Matsui et al. [158], by adopting bismuth, antimony and $\mathrm{Bi}_{1-\mathrm{x}} \mathrm{Sb}_{\mathrm{X}}$ alloys at different stoichiometries as anode materials for MIBs. Antimony showed very poor cycling performances, but bismuth and $\mathrm{Bi}_{0.88} \mathrm{Sb}_{0.12}$ alloy exhibited impressive results at a current density corresponding to $1 \mathrm{C}$ (see Table 3 ). The capacity fading detected by the authors was probably due to losses of electrical contact caused by periodic volume change of the anode during cycling.

Table 3. Performances of $\mathrm{Mg}$ cells assembled with $\mathrm{Bi}$ and $\mathrm{Bi}_{0.88} \mathrm{Sb}_{0.12}$ anodes.

\begin{tabular}{ccc}
\hline & $\begin{array}{c}\text { Maximum Specific Capacity } \\
\left(\mathbf{m A h} \mathbf{~ g}^{-\mathbf{1})}\right.\end{array}$ & $\begin{array}{c}\text { Specific Capacity at the 100th } \\
\text { Cycle (mAh } \mathbf{~ g}^{\mathbf{- 1})}\end{array}$ \\
\hline $\mathrm{Bi}$ & 257 & 222 \\
\hline $\mathrm{Bi}_{0.88} \mathrm{Sb}_{0.12}$ & 298 & 215 \\
\hline
\end{tabular}

Shao et al. studied the electrochemical characteristics of bismuth nanotubes (NTs), synthesized by hydrothermal reaction [161]. The purpose was to reduce the diffusion length of magnesium ions in order to mitigate the kinetic hurdles that exist in alternative anode materials. The experiments were conducted for both bismuth NTs and microparticles, in $\mathrm{Mg}\left(\mathrm{BH}_{4}\right)_{2}+\mathrm{LiBH}_{4}$ diglyme electrolytes. Figure 7 displays the cyclic voltammograms $(\mathrm{CV})$, the discharge/charge profile and the rate/cycling performances of the cells assembled by Shao et al. The results clearly showed superior performances in the case of a bismuth nanostructured anode, especially at high $C$ rates (Figure 7c). At 5C, the specific capacity was $216 \mathrm{mAh} \mathrm{g}^{-1}$ for bismuth NTs vs. $51 \mathrm{mAh}^{-1}$ for bismuth microparticles. The former also showed narrower peaks and lower overpotential (Figure 7A), together with a faster response. At low $C$ rates, i.e., between $C / 20$ and $C / 2$, the performances of the two structures were almost comparable. Furthermore, bismuth NTs were studied in a full cell setup, by choosing $\mathrm{Mo}_{6} \mathrm{Se}_{8}$ as cathode and an electrolyte consisting of $\mathrm{Mg}(\mathrm{TFSI})_{2}$ $0.4 \mathrm{M}$ in diglyme. A mid-point discharge voltage of about $0.75 \mathrm{~V}$ and a specific capacity of $90 \mathrm{mAh} \mathrm{g}^{-1}$ were observed. The full cell also exhibited a $92.3 \%$ capacity retention after 200 cycles (Figure 7D). X-ray diffraction (XRD) analysis confirmed the high reversibility of magnesium ions insertion. A weakness, though, was the large voltage hysteresis between magnesium alloying and dealloying, which resulted in energy losses. Other drawbacks were the exotic nature of the anodic material and its manufacturing costs, which made it difficult to be used in large scale commercial systems [110]. 

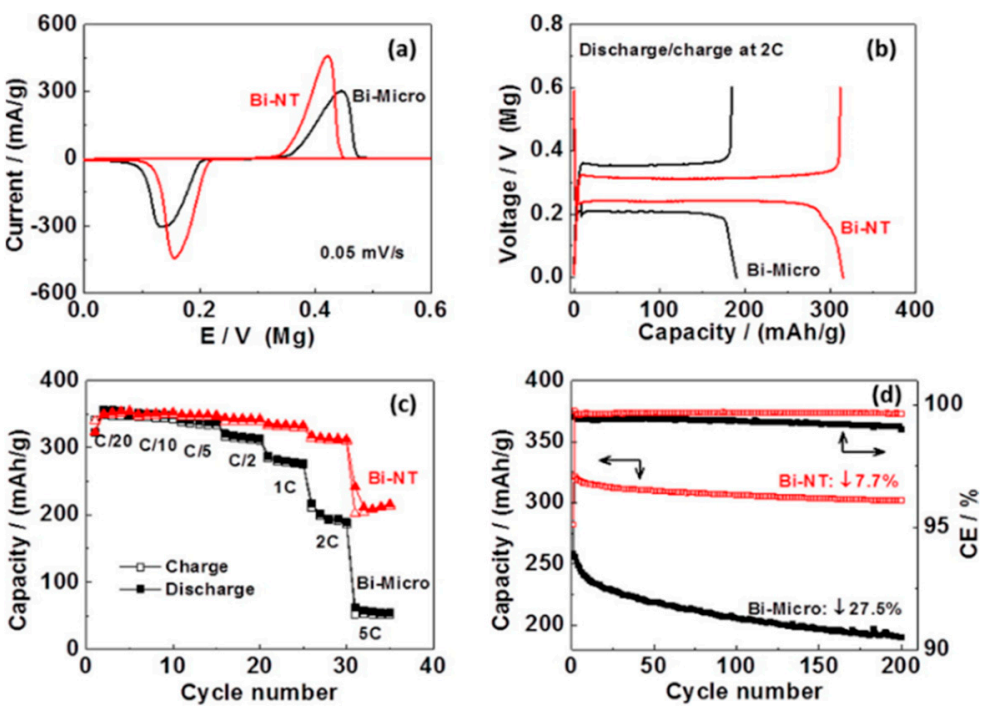

Figure 7. Electrochemical performances of bismuth NTs as anodes for MIBs: (a) Cyclic voltammograms (CV) of magnesium ions insertion/deinsertion; (b) Discharge/charge profile of a cell; (c) Rate performance of a cell; (d) Cycling stability and Coulombic efficiency of bismuth NTs for reversible magnesium ions insertion/deinsertion (C-rate was not reported by the authors). Cell configuration: $\mathrm{Mg} / \mathrm{Mg}\left(\mathrm{BH}_{4}\right)_{2} 0.1 \mathrm{M}+\mathrm{LiBH}_{4} 1.5 \mathrm{M}$ in diglyme/Bi. A comparison with the corresponding microstructured anodes is also shown in each plot. Adapted with permission from [161]. Copyright American Chemical Society, 2014.

The bismuth-based anode was also studied by Murgia et al. by electrochemical measurements coupled with XRD [162]. The experiments were conducted in two-electrode cells, which contained metallic magnesium as counter and reference electrodes and an organometallic-based electrolyte solution. An unexpected phenomenon was observed: a biphasic process occurred between bismuth and $\mathrm{Mg}_{3} \mathrm{Bi}_{2}$ without any intermediate amorphization, that is the rule for alloy-type electrodes. Micrometric bismuth and $\mathrm{Mg}_{3} \mathrm{Bi}_{2}$ prepared by ball-milling delivered specific capacity of $300 \mathrm{mAh} \mathrm{g}^{-1}$ at a discharge rate of 2C, with Coulombic efficiency of $98.5 \%$ after 50 cycles (Figure $8 \mathrm{~A}$ ). Moreover, a full cell composed by a $\mathrm{Mg}_{3} \mathrm{Bi}_{2}$ anode and $\mathrm{Mo}_{6} \mathrm{~S}_{8}$ cathode in a conventional electrolyte solution of $\mathrm{Mg}(\mathrm{TFSI})_{2} 0.5 \mathrm{M}$ in dyglime was developed. The full cell showed a voltage profile with a discharge plateau at around $0.6 \mathrm{~V}$. Both the intercalation process on the cathodic side and the de-alloying process of the anode during discharge were corroborated through ex situ XRD measurements. However, full de-magnesiation of $\mathrm{Mg}_{3} \mathrm{Bi}_{2}$ was not achieved.

Moreover, by ${ }^{25} \mathrm{Mg}$ nuclear magnetic resonance spectroscopy, aimed at understanding the mechanism and diffusion pathway for magnesium ions in the bismuth anode [163], two-phase alloying reactions of magnesium and bismuth were demonstrated, and such spectroscopy studies enlightened a fast exchange between the two magnesium sites in the $\mathrm{Mg}_{3} \mathrm{Bi}_{2}$ alloy.

Di Leo et al. proposed the synthesis of bismuth/carbon nanotubes (CNTs) composite [159]. Electrochemical deposition of bismuth on CNTs from aqueous solution of $\mathrm{Bi}\left(\mathrm{NO}_{3}\right)_{3}$ was adopted to obtain the composite material. They observed a specific capacity of $180 \mathrm{mAh} \mathrm{g}^{-1}$ through $\mathrm{CV}$ at a rate of $0.5 \mathrm{mV} \mathrm{s}^{-1}$ in acetonitrile-based solution containing $\mathrm{Mg}\left(\mathrm{ClO}_{4}\right)_{2} 0.5 \mathrm{M}$ and dipropylene glycol dimethyl ether $0.5 \mathrm{M}$. However, the capacity decreased to $80 \mathrm{mAh} \mathrm{g}^{-1}$ at the second cycle and to $49 \mathrm{mAh} \mathrm{g}^{-1}$ at the third. This sharp capacity fading excluded the material from any further investigation. 

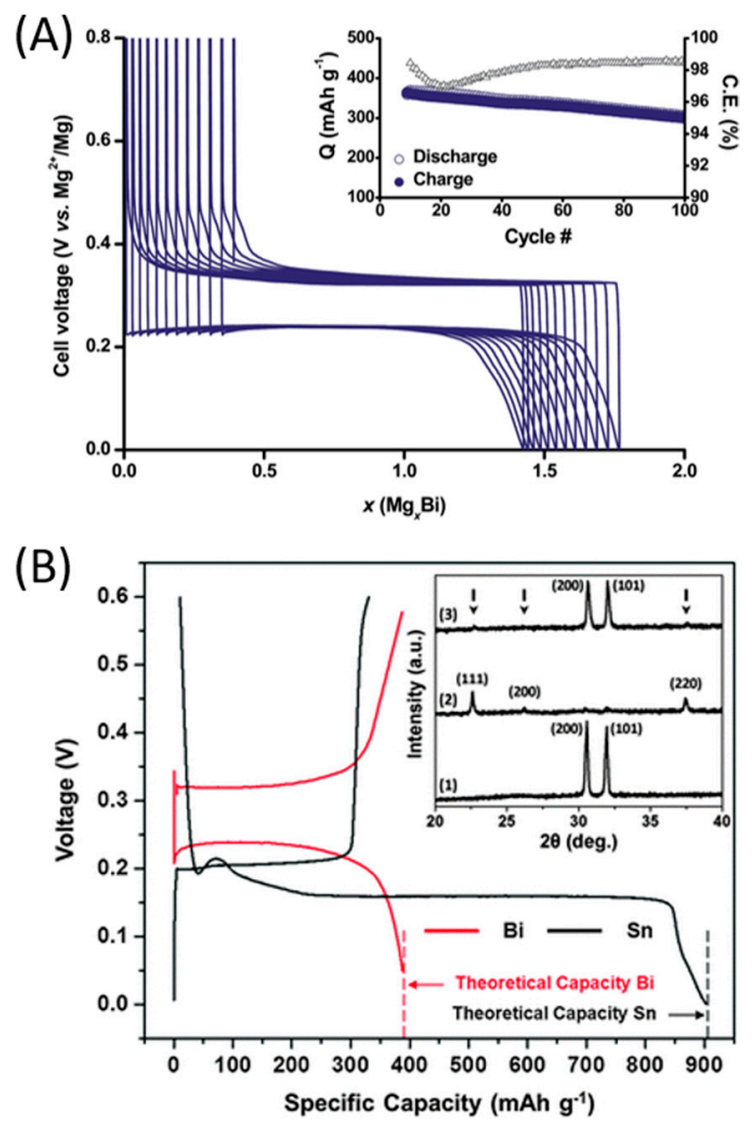

Figure 8. (A) Galvanostatic curve at 2C, after initial activation sweeps, obtained with copper foil supported electrode based on micrometric bismuth particles embedded by carbon additives. Inset: evolution of discharge and charge capacities and Coulombic efficiency. (B) First cycle galvanostatic magnesiation/de-magnesiation curves for $\mathrm{Sn} / \mathrm{Mg}$ and $\mathrm{Bi} / \mathrm{Mg}$ half cells (with organohaloaluminate electrolyte); inset: XRD spectra for (1) as-fabricated tin, (2) magnesiated tin (or $\mathrm{Mg}_{2} \mathrm{Sn}$ - peak positions marked with arrows) and (3) de-magnesiated $\mathrm{Mg}_{2} \mathrm{Sn}$. Adapted with permission from [162]. Copyright Royal Society of Chemistry, 2015. Adapted with permission from [26]. Copyright Informa UK Limited, 2017.

Some computational studies confirmed the great potential of bismuth-based materials to serve as anodes, despite some limits. A computational study by Jin et al. underlined that the diffusion barrier for an isolated magnesium ion in bismuth was $0.67 \mathrm{eV}$, a relatively low value, which does not change with the alloying level. This suggests the existence of a concrete possibility to obtain a fast charging/discharging magnesium battery, based on magnesium-bismuth alloys as anode [164].

\subsection{Tin-Based Anodes}

Another promising family of materials for MIBs alternative anodes is that of tin-based electrodes. Tin theoretically implies several advantages over bismuth as anode material [110]: (1) lower insertion potential; (2) higher theoretical specific capacity; (3) considerably lower atomic weight (118.71 $u$ for tin vs. $208.98 \mathrm{u}$ for bismuth); (4) Earth abundancy of tin is approximatively two orders of magnitude greater than that of bismuth. Furthermore, in the case of bismuth-based anodes each bismuth atom is able to exchange three electrons (see Equation (1)).

As for tin-based anode, the anodic alloy is $\mathrm{Mg}_{2} \mathrm{Sn}$ and its chemical reaction allows an exchange of four electrons for each tin atom, one more than what occurs for each bismuth atom:

$$
\mathrm{Sn}+2 \mathrm{Mg}^{2+}+4 \mathrm{e}^{-} \rightarrow \mathrm{Mg}_{2} \mathrm{Sn}
$$


Finally, tin offers better performances in terms of recycling than bismuth, as shown in Figure $4($ tin $>50 \%$, bismuth $<1 \%)$.

One of the first studies on this topic was that of Singh et al., based on tin powder films for insertion anodes [165]. By plotting galvanostatic charge-discharge curves for both tinand bismuth-based anodes at a low current density of $C / 500$ in an organo-haloaluminate electrolyte, the superior electrochemical performances of tin were put in light. The insertion potential into tin anode was found to be equal to $0.15 \mathrm{~V} \mathrm{vs}$. $\mathrm{Mg}^{2+} / \mathrm{Mg}$, against $0.23 \mathrm{~V}$ vs. $\mathrm{Mg}^{2+} / \mathrm{Mg}$ for the bismuth anode, and a hysteresis between insertion and de-insertion of $50 \mathrm{mV}$ was observed for tin, much lower than that of $90 \mathrm{mV}$ for bismuth. The tin anode showed an initial impressive specific capacity of $903 \mathrm{mAh} \mathrm{g}^{-1}$, but, unfortunately, the discharge process revealed to be highly irreversible, with a sharp reduction in reversible capacity (Figure 8B). Rate capability measurements also showed that, at rates above C/500, the specific capacity of the tin anode rapidly decreased. This was possibly due to a poor insertion kinetics of the tin anode, even though the Coulombic efficiency seemed to increase with the charge-discharge rate. The sharp reduction of initial capacity was also observed in full cell setups, with $\mathrm{Mg}(\mathrm{TFSI})_{2} 0.5 \mathrm{M}$ in DME/organohaloaluminate electrolyte and $\mathrm{Mo}_{6} \mathrm{~S}_{8}$ cathode. The resulting electrochemical performances were quite similar for both systems: $82 \mathrm{mAh} \mathrm{g}^{-1}$ at the first cycle, followed by a stable value of less than $50 \mathrm{mAh} \mathrm{g}^{-1}$ for the following ones [165].

Beyond pure tin, some tin-based compounds were also studied. Cheng et al., for example, focused on a tin-antimony alloy by means of a combined computational and experimental approach [166]. In their first study, they discovered that, during the first cycle, an irreversible process led to the formation of a porous structure composed of antimonyrich and pure tin sub-structures. After this initial phase (conditioning), they observed that the nanosized tin particles had a highly reversible behaviour, while the antimonyrich zones showed low Coulombic efficiency due to trapping. Thus, the antimony-rich zones lowered the specific capacity of the anode, but they seemed to be necessary to reach formation of stable tin nanoparticles [166]. Another study focused on the behaviour of the tin-antimony alloy after conditioning led to the conclusion that the alloy had superior properties than that of pure tin [167]. Overall, the advantages of the tin-antimony alloy can be summarized as follows: (1) improved kinetics for magnesiation/demagnesiation result in lower overpotentials (Figure 9A); (2) improved specific capacity at the same current density ( $420 \mathrm{mAh} \mathrm{g}^{-1}$ vs. less than $300 \mathrm{mAh} \mathrm{g}^{-1}$ for pure tin at a $50 \mathrm{~mA} \mathrm{~g}^{-1}$ ) (Figure 9B); (3) excellent rate capability with $70 \%$ capacity retention $\left(300 \mathrm{~mA} \mathrm{~g}^{-1}\right.$ at very high current densities of $1000 \mathrm{~mA} \mathrm{~g}^{-1}$ (Figure 9C); (4) good cyclability, with $270 \mathrm{mAh} \mathrm{g}^{-1}$ after 200 cycles at a current density of $500 \mathrm{~mA} \mathrm{~g}^{-1}$ (Figure 9D).

Wang et al. used density functional theory (DFT) calculations to study magnesium cation diffusion properties in $\beta$ - and $\alpha$-Sn. They found a diffusion barrier for an isolated magnesium atom of $0.395 \mathrm{eV}$ in the $\alpha-S n$ and of $0.435 \mathrm{eV}$ in the $\beta-S n$. Moreover, a higher magnesium concentration decreased the diffusion barrier in the case of $\alpha$-Sn, while an opposite behaviour was expected for $\beta$-Sn. Thus, the $\alpha$ form of tin seemed to represent a better alternative than the $\beta$ phase as an anode material for MIBs [168]. 

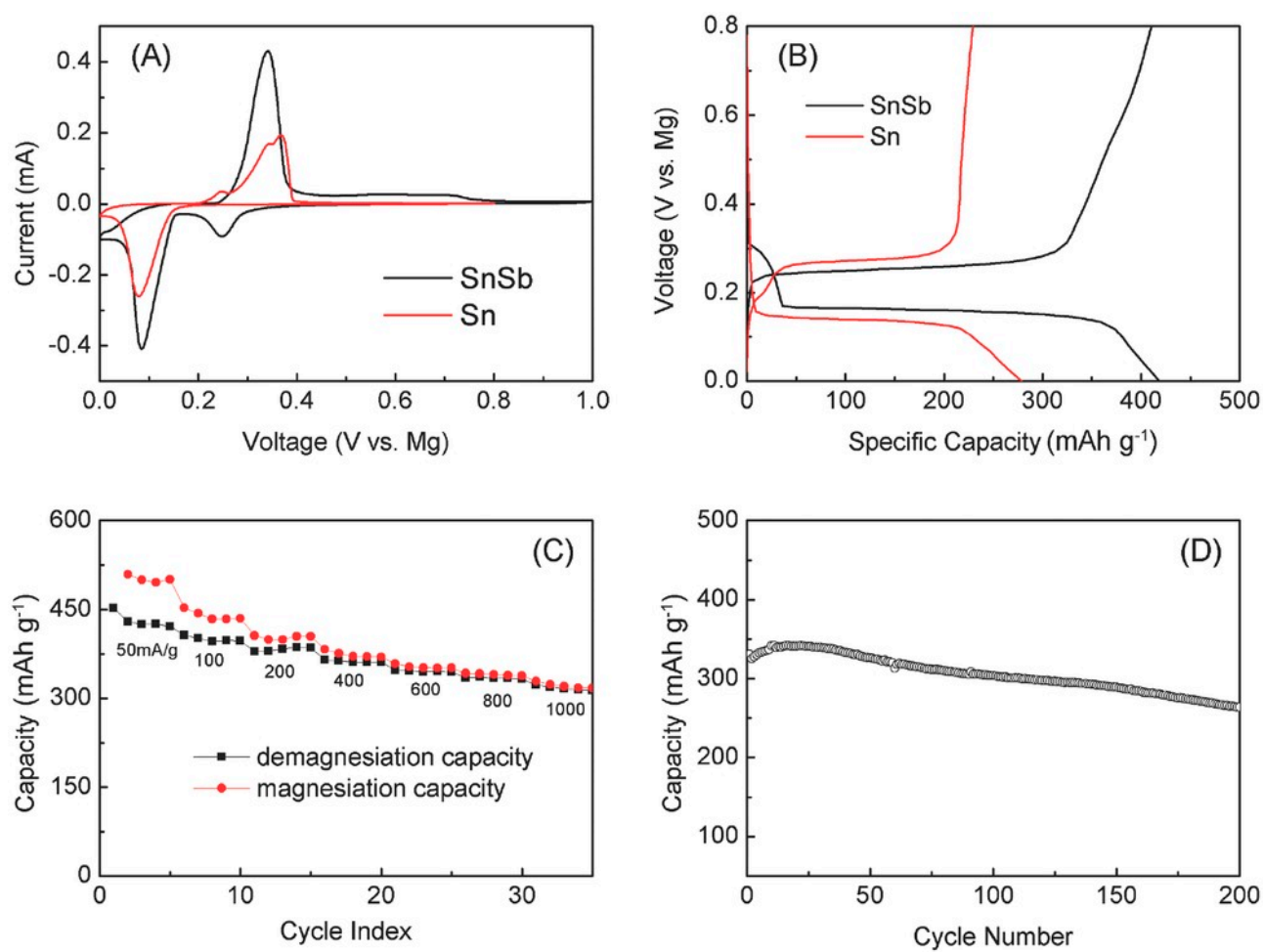

Figure 9. Comparison of electrochemical behaviour of tin-antimony alloy and tin towards magnesiation/de-magnesiation: (A) CV carried out at $0.05 \mathrm{mV} \mathrm{s}^{-1}$; (B) Charge-discharge profiles at $50 \mathrm{~mA} \mathrm{~g}^{-1}$; (C) Specific capacity at different current densities when using the tin-antimony alloy; (D) Cycling stability of the tin-antimony alloy at $500 \mathrm{~mA} \mathrm{~g}^{-1}$. Adapted with permission from [167]. Copyright American Chemical Society, 2015.

\subsection{Biphasic Bismuth-Tin Alloy Anodes}

As said above, both bismuth and tin anodes show interesting properties, but also have some drawbacks. Bismuth anode does not deliver highly specific capacities, while the tin anode experiences strong capacity fading and irreversible chemistry, due to the sluggish solid-state diffusion of magnesium ions and slow charge transfer at the interface [169]. Interfacial design would be a good way to improve ionic transport properties, as phase/grain boundaries act as channels for magnesium ions. Designing biphasic or multiphase alloys, rather than single phase, would be a clever strategy to increase the density of phase/grain boundaries, so that a better transport of magnesium ions would be allowed and kinetics of the electrode would be improved [170].

Biphasic bismuth-tin alloys were proposed and discussed in a recent study [170], expected to combine the high capacity of tin with the good reversibility of bismuth. A facile dealloying strategy was developed, with an alternate phase distribution and a nanoporous structure (NP) thanks to which volume expansion is mitigated and diffusion length is shortened. During the discharge process, bismuth and tin consecutively react with magnesium ions to form $\mathrm{Mg}_{3} \mathrm{Bi}_{2}$ and $\mathrm{Mg}_{2} \mathrm{Sn}$, respectively, while the charge process brings to de-magnesiation of $\mathrm{Mg}_{3} \mathrm{Bi}_{2}$ and $\mathrm{Mg}_{2} \mathrm{Sn}$ to regenerate bismuth and tin. High performances were observed, mainly thanks to the porous structure, the dual-phase microstructure and the high density of phase/grain boundaries. Figure 10A schematically shows the increased grain boundaries and magnesium ions transport channels on the atomic scale that is possible to obtain after the first cycle in a dual-phase bismuth-tin electrode. Two different alloys were tested, i.e., $\mathrm{Bi}_{6} \mathrm{Sn}_{4}$ and $\mathrm{Bi}_{4} \mathrm{Sn}_{6}$, synthesized by chemical dealloying of rapidly solidified $\mathrm{Mg}_{90} \mathrm{Bi}_{6} \mathrm{Sn}_{4}\left(\right.$ at \%) and $\mathrm{Mg}_{90} \mathrm{Bi}_{4} \mathrm{Sn}_{6}$ (at \%) precursor ribbons in a $2 \mathrm{wt} \%$ tartaric acid solution at ambient temperature. Scanning electron microscopy (SEM) images of the two alloys are shown in Figure 10B,C. Their theoretical specific capacities were 623 and $525 \mathrm{mAh} \mathrm{g}^{-1}$, respectively. 


\section{Atoms in the grain boundaries $\quad$ Atoms in the grains $\longrightarrow \mathrm{Mg}^{2+}$ transport}
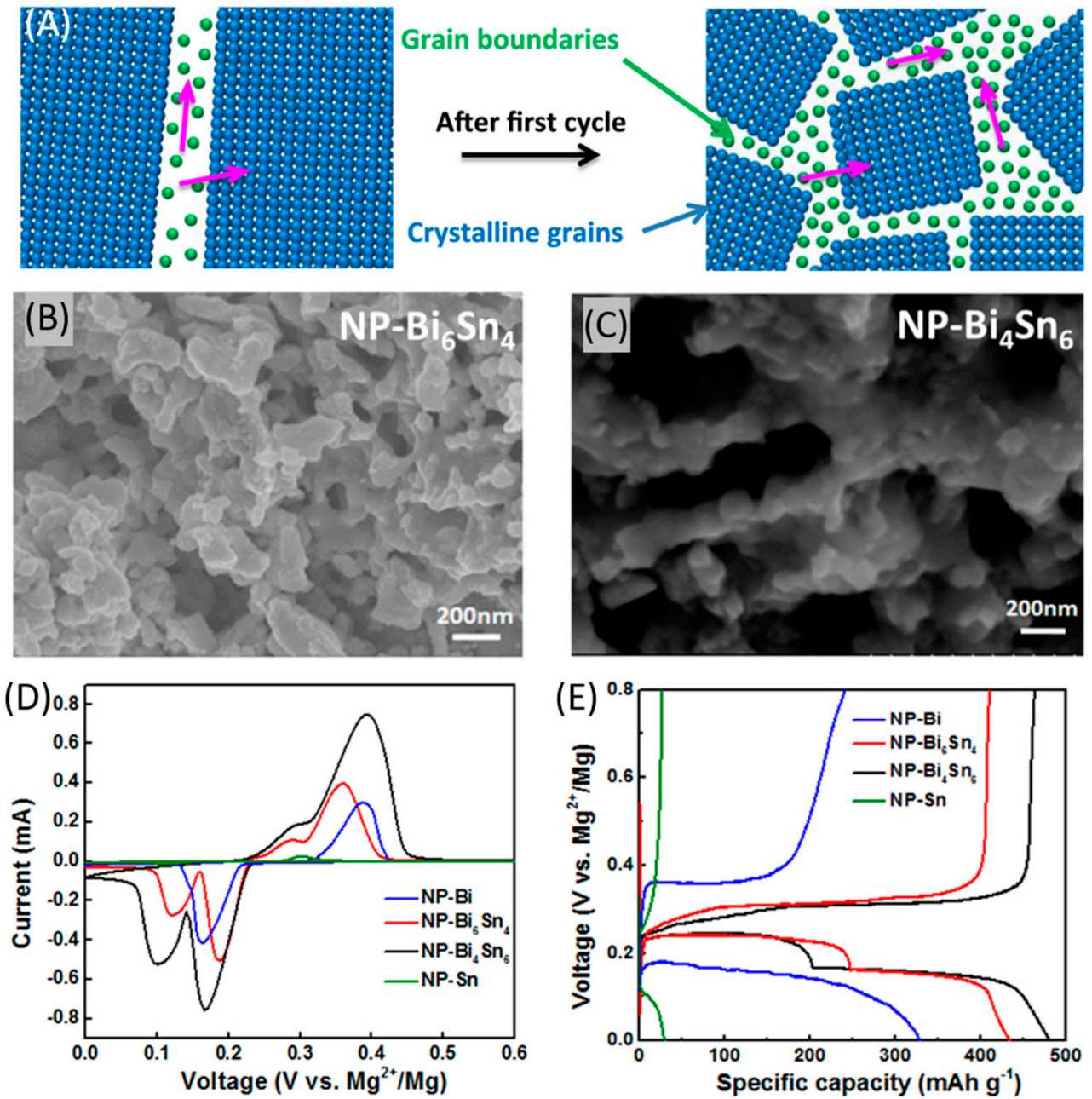

Figure 10. (A) The increased grain boundaries on the atomic scale after the first cycle and the enhanced magnesium ions transport; SEM images of (B) NP-Bi ${ }_{6} \mathrm{Sn}_{4}$ and (C) NP-Bi $\mathrm{Sn}_{6}$; (D) CV curves for NP-bismuth and alloy electrodes at a scan rate of $0.05 \mathrm{mV} \mathrm{s}^{-1}$ and for NP-tin at $0.01 \mathrm{mV} \mathrm{s}^{-1}$ for the first cycle; (E) Discharge/charge profiles for NP-bismuth and alloy electrodes acquired at $50 \mathrm{~mA} \mathrm{~g}^{-1}$ and for NP-tin at $20 \mathrm{~mA} \mathrm{~g}^{-1}$. Adapted with permission from [170]. Copyright Elsevier B.V., 2018.

MIB performances with these alloys were studied in an all-phenyl-complex $0.4 \mathrm{M}$ electrolyte. Cells were composed of a magnesium foil and the alloy as electrodes, and comparison with NP-bismuth and NP-tin electrodes was also carried out. Figure 10D shows the resulting $\mathrm{CV}$ traces, at the scan rate of $0.05 \mathrm{mV} \mathrm{s}^{-1}$ for NP-bismuth and alloy electrodes, and at $0.01 \mathrm{mV} \mathrm{s}^{-1}$ for NP-tin within the voltage range of $0-0.6 \mathrm{~V} \mathrm{vs.} \mathrm{Mg}^{2+} / \mathrm{Mg}$. It is possible to observe a larger peak area for the $\mathrm{NP}-\mathrm{Bi}_{4} \mathrm{Sn}_{6}$ electrode than that for the $\mathrm{NP}-\mathrm{Bi}_{6} \mathrm{Sn}_{4}$ one, suggesting a higher specific capacity. For the two alloys, a two-step reversible magnesiation and de-magnesiation reaction occurred, associated to two couples of redox peaks. This was attributed to the biphasic nature of the alloys. The relatively small redox peaks of the NP-tin electrode were explained by its low reactivity and inferior kinetics. Galvanostatic discharge/charge profiles of the NP-bismuth and alloy electrodes (at a current density of $50 \mathrm{~mA} \mathrm{~g}^{-1}$ ) and of NP-tin sample (at $20 \mathrm{~mA} \mathrm{~g}^{-1}$ ) within the voltage range of $0-0.8 \mathrm{~V}$ vs. $\mathrm{Mg}^{2+} / \mathrm{Mg}$ (Figure $10 \mathrm{E}$ ) showed that $\mathrm{NP}-\mathrm{Bi}_{6} \mathrm{Sn}_{4}$ and $\mathrm{NP}-\mathrm{Bi}_{4} \mathrm{Sn}_{6}$ electrodes managed to deliver high values of discharge specific capacities equal to 434 and $482 \mathrm{mAh}^{-1}$, respectively. These values were much higher than those of NP-bismuth and NP-tin, i.e., $330 \mathrm{mAh} \mathrm{g}^{-1}$ at $50 \mathrm{~mA} \mathrm{~g}^{-1}$ for NP-bismuth and only $31 \mathrm{mAh} \mathrm{g}^{-1}$ even 
at $20 \mathrm{~mA} \mathrm{~g}^{-1}$ for NP-tin. These results were consistent with the redox peaks displayed by the $\mathrm{CV}$.

Galvanostatic profiles also helped to understand the chemical processes that occurred during discharge and charge of the biphasic bismuth-tin electrode. During discharge, it was possible to observe two plateaus at around 0.16 and $0.23 \mathrm{~V} \mathrm{vs.} \mathrm{Mg}^{2+} / \mathrm{Mg}$. They were associated to the magnesiation processes successively occurring in bismuth and tin. During charge, a sloped plateau $\left(0.25-0.32 \mathrm{~V}\right.$ vs. $\left.\mathrm{Mg}^{2+} / \mathrm{Mg}\right)$ followed by a second one at about $0.33 \mathrm{~V}$ vs. $\mathrm{Mg}^{2+} / \mathrm{Mg}$ were the expression of the de-magnesiation processes and the regeneration of tin and bismuth. Biphasic electrodes were characterized by a much lower hysteresis between magnesiation and de-magnesiation curves if compared to both NPbismuth and NP-tin samples, due to decreased polarization effect. Finally, it was possible to extrapolate the contribution of bismuth and tin to the final specific capacity of $\mathrm{NP}-\mathrm{Bi}_{4} \mathrm{Sn}_{6}$ and $\mathrm{NP}_{-} \mathrm{Bi}_{6} \mathrm{Sn}_{4}$ (see Table 4). The alloy with the highest content of bismuth was expected to achieve superior performances because of the relatively small volume changes of bismuth and faster diffusion kinetics, with formation of the superionic conductor $\mathrm{Mg}_{3} \mathrm{Bi}_{2}$.

Table 4. Performances of Mg cells assembled with NP-Bi $\mathrm{Sn}_{6}$ and NP-Bi ${ }_{6} \mathrm{Sn}_{4}$ anodes, with a focus on the contribution of each metal.

\begin{tabular}{ccc}
\hline & Contribution of Bi (mAh $\left.\mathbf{g}^{-1}\right)$ & Contribution of Sn (mAh $\left.\mathbf{g}^{-\mathbf{1}}\right)$ \\
\hline $\mathrm{NP}-\mathrm{Bi}_{4} \mathrm{Sn}_{6}$ & 202 & 280 \\
\hline $\mathrm{NP}-\mathrm{Bi}_{6} \mathrm{Sn}_{4}$ & 246 & 188 \\
\hline
\end{tabular}

Rate capability was also analysed (Figure 11A). The results showed excellent rate capability performances for $\mathrm{NP}_{-} \mathrm{Bi}_{6} \mathrm{Sn}_{4}$. In addition, its discharge capacity of $434 \mathrm{mAh} \mathrm{g}^{-1}$ at $50 \mathrm{~mA} \mathrm{~g}^{-1}$ gradually decreased with increasing current densities, but at $1000 \mathrm{~mA} \mathrm{~g}^{-1}$ it was still equal to $362 \mathrm{mAh} \mathrm{g}^{-1}$ (Figure 11B). The tin phase was responsible of the majority of capacity fading with increasing currents. At $1000 \mathrm{~mA} \mathrm{~g}^{-1}$, the bismuth phase capacity contribution showed a $6 \%$ fading with respect to its contribution at $50 \mathrm{mAh} \mathrm{g}^{-1}$, against $30.3 \%$ for tin. A similar trend was observed for $\mathrm{NP}-\mathrm{Bi}_{4} \mathrm{Sn}_{6}$. Figure $11 \mathrm{C}$ also displays that the Coulombic efficiency of $\mathrm{NP}-\mathrm{Bi}_{6} \mathrm{Sn}_{4}$, initially relatively low $(94.5 \%)$, gradually increased as the rate raised: the reason was attributed to the reduction of reacting quantity of tin, which was responsible of the capacity fading. At $1000 \mathrm{~mA} \mathrm{~g}^{-1}$, because of the higher content of tin, $\mathrm{NP}-\mathrm{Bi}_{4} \mathrm{Sn}_{6}$ showed a specific capacity of $260 \mathrm{mAh} \mathrm{g}^{-1}$, but it must be considered that capacity of NP-bismuth collapsed to $7 \mathrm{mAh} \mathrm{g}^{-1}$ under the same current density. The tin phase was thus essential to reach good performances at high current densities. As concerns cycling stability, the bismuth-tin alloy showed excellent results. Figure $11 \mathrm{C}$ displayed, for comparison, cycling performance of NP-bismuth and alloy samples at $200 \mathrm{~mA} \mathrm{~g}^{-1}$, while that of NP-tin was recorded at $20 \mathrm{~mA} \mathrm{~g}^{-1}$. Figure 11D shows discharge/charge profiles of $\mathrm{NP}-\mathrm{Bi}_{6} \mathrm{Sn}_{4}$ for different cycles at $200 \mathrm{~mA} \mathrm{~g}^{-1}$. 

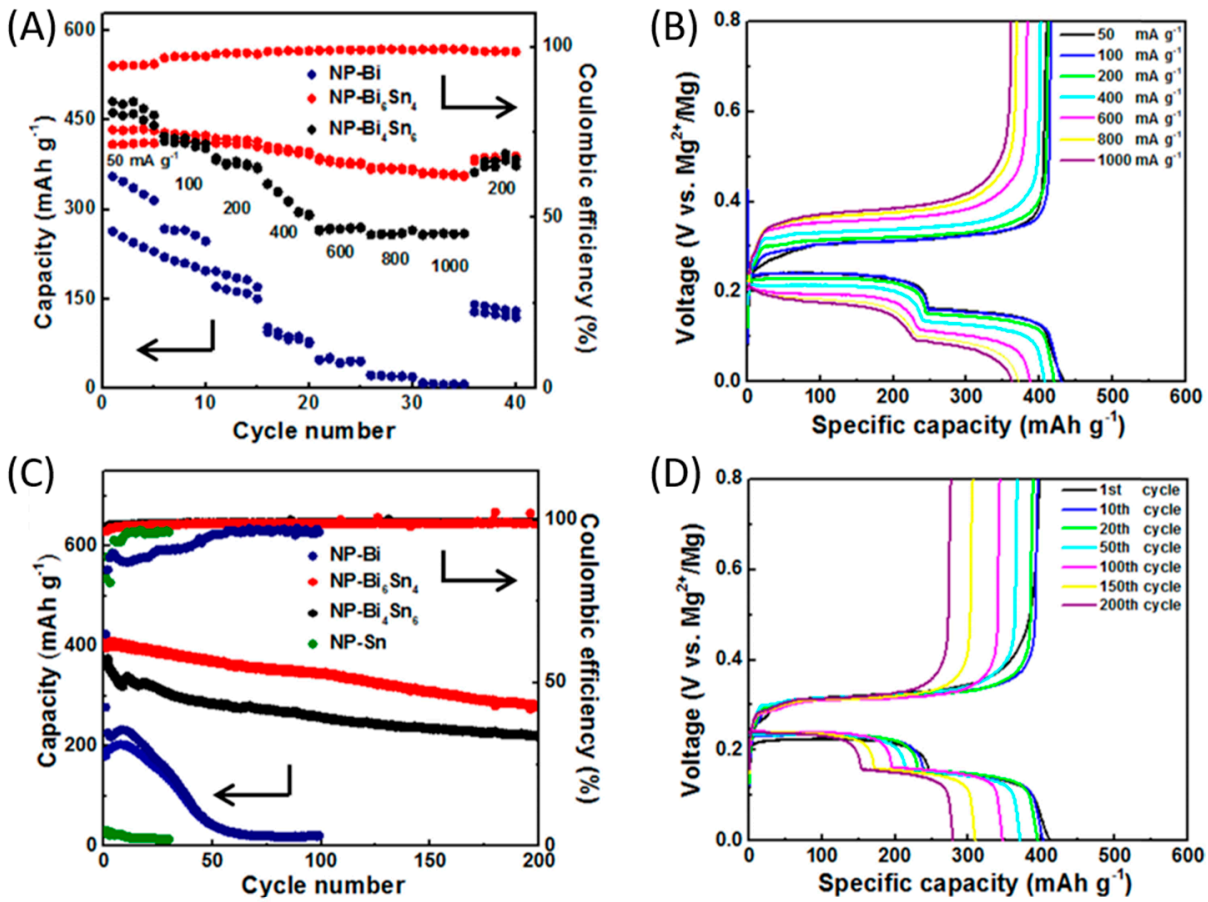

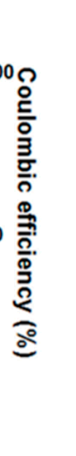

Dual phase Bi-Sn

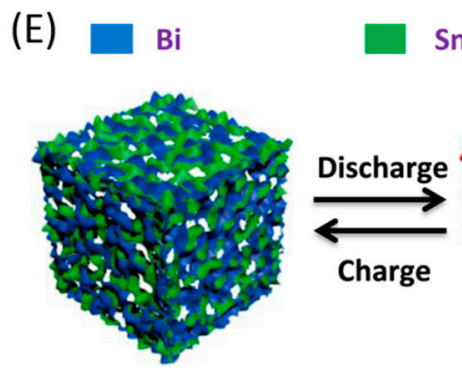

Sn

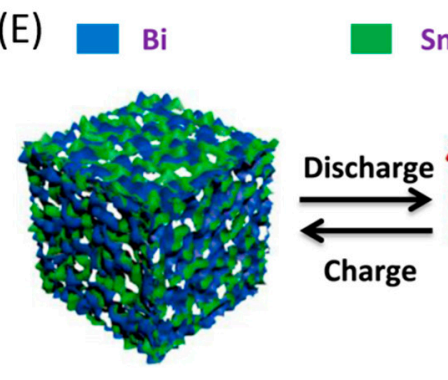

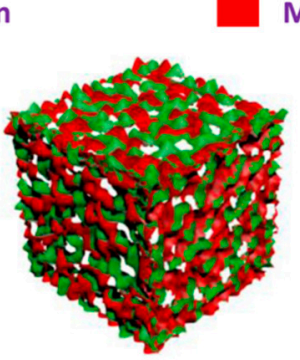

$\mathrm{Mg}_{3} \mathrm{Bi}_{2} / \mathrm{Sn}$

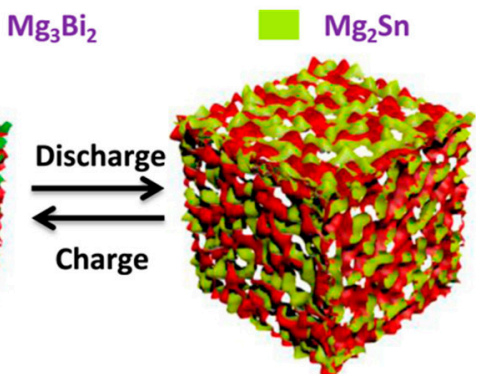

$\mathrm{Mg}_{3} \mathrm{Bi}_{2} / \mathrm{Mg}_{2} \mathrm{Sn}$

Figure 11. (A) Rate performance for NP-bismuth and alloy electrodes; (B) Discharge/charge profiles for NP-Bi ${ }_{6} \mathrm{Sn}_{4}$ electrode at different current densities; (C) Cycling stability of NP-bismuth and alloy electrode at $200 \mathrm{~mA} \mathrm{~g}^{-1}$ and of NP-tin at $20 \mathrm{~mA} \mathrm{~g}^{-1}$; (D) Discharge/charge profiles of NP-Bi ${ }_{6} \mathrm{Sn}_{4}$ electrode for different cycles at $200 \mathrm{~mA} \mathrm{~g}^{-1}$; (E) Schematic illustration of the electrochemical reaction mechanisms of alloy electrodes. Adapted with permission from [170]. Copyright Elsevier B.V., 2018.

Bismuth-tin alloy stability was clearly superior. NP-Bi ${ }_{6} \mathrm{Sn}_{4}$ specific capacity decreased from $412 \mathrm{mAh} \mathrm{g}^{-1}$ at the first cycle to $280 \mathrm{mAh} \mathrm{g}^{-1}$ at the $200 \mathrm{th}$, namely $68 \%$ capacity retention. Thanks to the discharge/charge profiles (Figure 11D), it was possible to extrapolate the role that bismuth and tin played in the capacity fading, as shown in Table 5. The results interestingly showed that, upon cycling, the specific capacity of the bismuth phase decayed faster than that of tin phase: this was probably caused by the dual-phase nature of the electrode, which unlocked the kinetics limitations of the tin phase, leading to a highly reversible chemistry. As for $\mathrm{NP}-\mathrm{Bi}_{4} \mathrm{Sn}_{6}$ electrode, specific capacity rapidly decreased from 374 to $336 \mathrm{mAh} \mathrm{g}^{-1}$ during the initial 10 cycles, resulting in $10 \%$ capacity fading. This sharp difference with the behaviour of $\mathrm{NP}-\mathrm{Bi}_{6} \mathrm{Sn}_{4}$ was attributable to the different amount of bismuth and tin in the alloy; indeed, a part of tin failed to participate in the reaction after 10 cycles, at $200 \mathrm{mAh} \mathrm{g}^{-1}$. It was suggested that $\mathrm{NP}-\mathrm{Bi}_{4} \mathrm{Sn}_{6}$, in which the tin phase was dominant, could hardly accommodate large volume changes with high current densities during the initial cycles, as the volume change of $214 \%$ during the phase transformation between tin and $\mathrm{Mg}_{2} \mathrm{Sn}$ was larger than that of $100 \%$ between bismuth and $\mathrm{Mg}_{3} \mathrm{Bi}_{2}$. After 200 cycles, NP-Bi $4 \mathrm{Sn}_{6}$ capacity decreased from 374 to $220 \mathrm{mAh} \mathrm{g}^{-1}$, with $58.8 \%$ capacity retention (vs. $68 \%$ for $\mathrm{NP}-\mathrm{Bi}_{6} \mathrm{Sn}_{4}$ ). However, the Coulombic efficiency of both the biphasic 
alloys was very high, approximatively $99 \%$ after 30 cycles, because of the highly reversible behaviour of the two phases of bismuth and tin (Figure 11C).

Table 5. Performances of $\mathrm{Mg}$ cells assembled with $\mathrm{NP}-\mathrm{Bi}_{6} \mathrm{Sn}_{4}$ anode, with a focus on the contribution of each metal at different stages of the charge/discharge experiments.

\begin{tabular}{ccccc}
\hline $\begin{array}{c}\text { Contribution of Bi to } \\
\text { Initial Specific } \\
\text { Capacity }\end{array}$ & $\begin{array}{c}\text { Contribution of Bi to } \\
\text { Specific Capacity at the } \\
\text { 200th Cycle }\end{array}$ & $\begin{array}{c}\text { Percentage of Capacity } \\
\text { Fading of Bi }\end{array}$ & $\begin{array}{c}\text { Contribution of Sn to } \\
\text { Initial Specific } \\
\text { Capacity }\end{array}$ & $\begin{array}{c}\text { Contribution of Sn to } \\
\text { Specific Capacity at the } \\
\text { 200th Cycle }\end{array}$ \\
\hline $248 \mathrm{mAh} \mathrm{g}^{-1}$ & $154 \mathrm{mAh} \mathrm{g}^{-1}$ & $37.9 \%$ & $164 \mathrm{mAh} \mathrm{g}^{-1}$ & $126 \mathrm{mAh} \mathrm{g}^{-1}$ \\
\hline
\end{tabular}

The chemical processes occurring within the electrode during charge and discharge are sketched in Figure 11E, and can be summarized as follows. During discharge (alloying), at first magnesium ions reacted with bismuth to form $\mathrm{Mg}_{3} \mathrm{Bi}_{2}$, while the unreacted tin behaved as a buffer matrix mitigating volume expansion. Then, magnesium ions reacted with tin and the previously formed $\mathrm{Mg}_{3} \mathrm{Bi}_{2}$ played the role of preventing further volume expansion. The dual phase unlocked the potential properties of tin, that otherwise would be characterized by poor kinetics and low electrochemical reactivity. Meanwhile, $\mathrm{Mg}_{3} \mathrm{Bi}_{2}$ acted as a superionic conductor [160], accelerating the magnesium ions transport and explaining the better rate performances of $\mathrm{NP}-\mathrm{Bi}_{6} \mathrm{Sn}_{4}$, in which the bismuth phase was dominant. During the first charge (dealloying) process, magnesium ions were extracted from the electrode, bringing to formation of smaller-sized bismuth and tin nanocrystals. While the process occurred, $\mathrm{Mg}_{3} \mathrm{Bi}_{2}$ and tin served as a buffer matrix to prevent large volume shrinkage. Formation of the buffer matrix during charge and discharge, the unlocked potential of tin and the behaviour of $\mathrm{Mg}_{3} \mathrm{Bi}_{2}$ as a superionic conductor, combined with the effects of the porous structure and the increased density of grain/phase boundaries, explained all the good properties provided by the dual-phase bismuth-tin alloys [170].

\subsection{Titanium-Based Anodes}

Titanium-based anodic materials have been extensively studied for lithium- and sodium-based batteries [171-175], together with a broad examination of nanostructures and morphologies able to guarantee mechanical stability, high performance, ease of preparation on metal supports and efficient charge transport in one-dimensional materials. However, studies on titanium-based anodes in the field of MIBs are still few and the scientific community started publishing the first results in 2020.

Luo et al. proposed layered sodium trititanate $\left(\mathrm{Na}_{2} \mathrm{Ti}_{3} \mathrm{O}_{7}\right)$ and sodium hexatitanate $\left(\mathrm{Na}_{2} \mathrm{Ti}_{6} \mathrm{O}_{13}\right)$ nanowires (NWs) as anodes for MIBs [176]; they were prepared by heat treatment of the titanate precursor under different washing conditions. The investigation highlighted that passing from the layered $\mathrm{Na}_{2} \mathrm{Ti}_{3} \mathrm{O}_{7}$ morphology to a more condensate three-dimensional microporous structure in $\mathrm{Na}_{2} \mathrm{Ti}_{6} \mathrm{O}_{13}$ boosted the magnesium ions storage performance. The two electrodes exhibited a NWs-based morphology (Figure 12A,B); transmission electron microscopy (TEM) images showed that $\mathrm{Na}_{2} \mathrm{Ti}_{3} \mathrm{O}_{7}$ displayed a large interlayer spacing of $0.84 \mathrm{~nm}$, while for $\mathrm{Na}_{2} \mathrm{Ti}_{6} \mathrm{O}_{13}$ was equal to $0.75 \mathrm{~nm}$. Overall, the interlayer distance was rather large, enough to guarantee an efficient magnesium ions storage and diffusion. $\mathrm{Na}_{2} \mathrm{Ti}_{6} \mathrm{O}_{13}$-based cells achieved initial discharge and charge capacity of 165.8 and $147.7 \mathrm{mAh} \mathrm{g}^{-1}$, respectively, at $10 \mathrm{~mA} \mathrm{~g}^{-1}$, with an outstanding initial coulombic efficiency of $89.1 \%$ (Figure 12C). The electrochemical reaction mechanism was investigated through different techniques, from which it emerged that the inserted magnesium ions replaced the sites of sodium ions to form $\mathrm{Mg}-\mathrm{Ti}-\mathrm{O}$. In this system, sodium ions could not reinsert into the structure because of the formation of insoluble $\mathrm{NaCl}$ particles. Such an irreversible structure change and $\mathrm{NaCl}$ salt formation led to a rapid worsening of $\mathrm{Na}_{2} \mathrm{Ti}_{3} \mathrm{O}_{7}$-based cells specific capacity values. On the other hand, $\mathrm{Na}_{2} \mathrm{Ti}_{6} \mathrm{O}_{13}$, with its regular three dimensional and microporous structure based on $\mathrm{TiO}_{6}$ octahedra, guaranteed better structural stability during the magnesium ions insertion and extraction processes. 

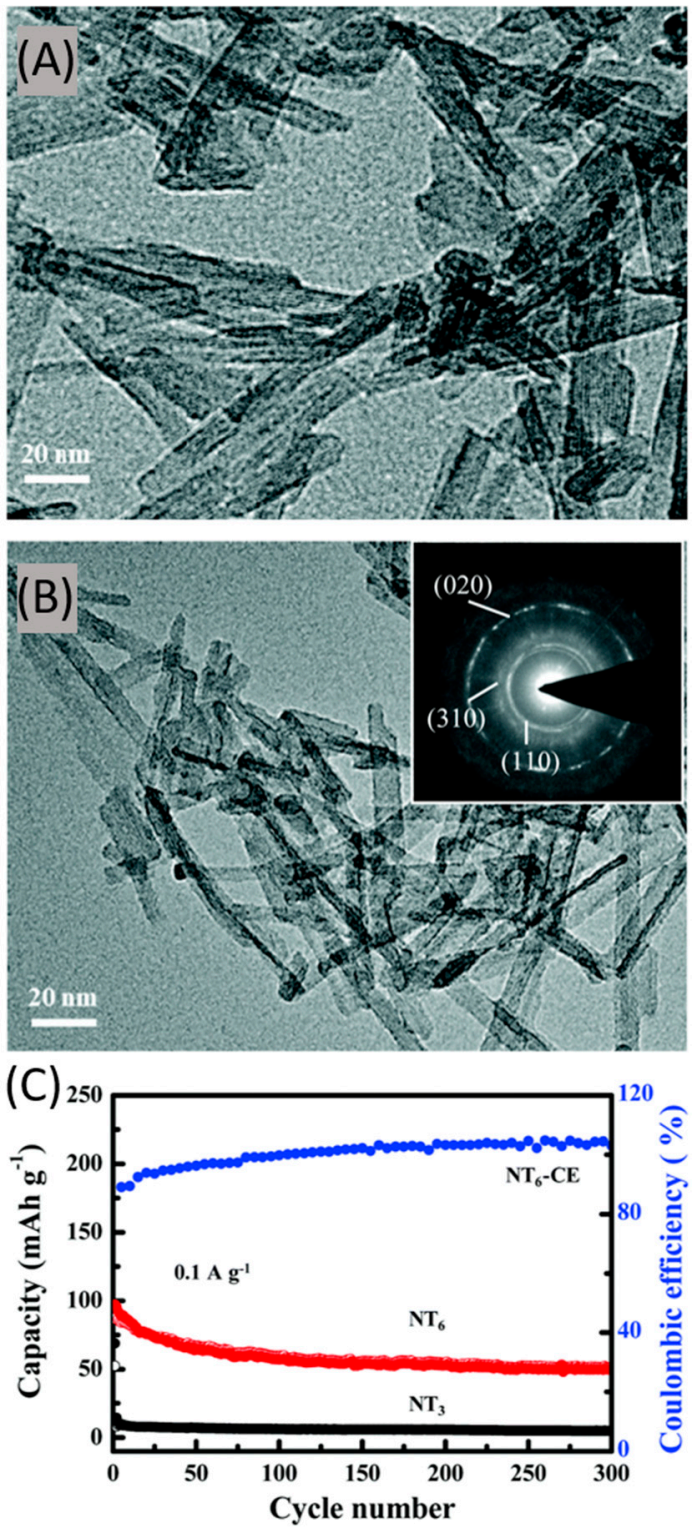

Figure 12. Transmission electron microscopy (TEM) images of (A) $\mathrm{Na}_{2} \mathrm{Ti}_{3} \mathrm{O}_{7} \mathrm{NWs}$ and $(\mathbf{B}) \mathrm{Na}_{2} \mathrm{Ti}_{6} \mathrm{O}_{13}$ NWs; (C) Cycling performance of $\mathrm{Na}_{2} \mathrm{Ti}_{3} \mathrm{O}_{7}$ and $\mathrm{Na}_{2} \mathrm{Ti}_{6} \mathrm{O}_{13} \mathrm{NWs}$ at $0.1 \mathrm{~A} \mathrm{~g}^{-1}$. Adapted with permission from [177]. Copyright American Chemical Society, 2020.

Yang et al. fabricated an original magnesium-ion dual-ion battery adopting expanded graphite as cathode and Ti-doped $\mathrm{Nb}_{2} \mathrm{O}_{5}$ nanoflakes (Ti- $\mathrm{Nb}_{2} \mathrm{O}_{5} \mathrm{NFs}$ ) as anode [177]. The latter was designed with the aim of shortening the diffusion distance of $\mathrm{Mg}^{2+}$ and consisted of a hierarchical structure including microspheres (diameter: 4-5 $\mu \mathrm{m}$ ) assembled by nanoflakes (Figure 13A-C). As a further innovative point, ether solvents with high inflammability and narrow electrochemical window were excluded from the electrolyte, and replaced with an ionic liquid-based solution containing $\mathrm{Mg}(\mathrm{TFSI})_{2} 0.5 \mathrm{M}$ in $\mathrm{Pyr}_{14} \mathrm{TFSI}$ (with additives). The resulting dual-ion battery (i.e., during charging magnesium ions intercalated into the $\mathrm{Ti}-\mathrm{Nb}_{2} \mathrm{O}_{5} \mathrm{NFs}$, while TFSI ${ }^{-}$ions intercalated into an expanded graphite, see Figure 13D) showed a high discharge capacity (93 $\mathrm{mAh} \mathrm{g}^{-1}$ ) at 1C and a capacity retention of $79 \%$ after 500 cycles at 3C (Figure 13E) and 77\% at 5C. Such a very good rate performance coupled with a rather high discharge medium voltage of $\approx 1.83 \mathrm{~V}$; the latter resulted in a high energy density $\left(174 \mathrm{Wh} \mathrm{kg}^{-1}\right.$ at $183 \mathrm{~W} \mathrm{~kg}^{-1}$ and $122 \mathrm{Wh} \mathrm{kg}^{-1}$ at $845 \mathrm{~W} \mathrm{~kg}^{-1}$ ), currently the best values in the field and that could be successfully led to device integration with solar cells [178-182]. 

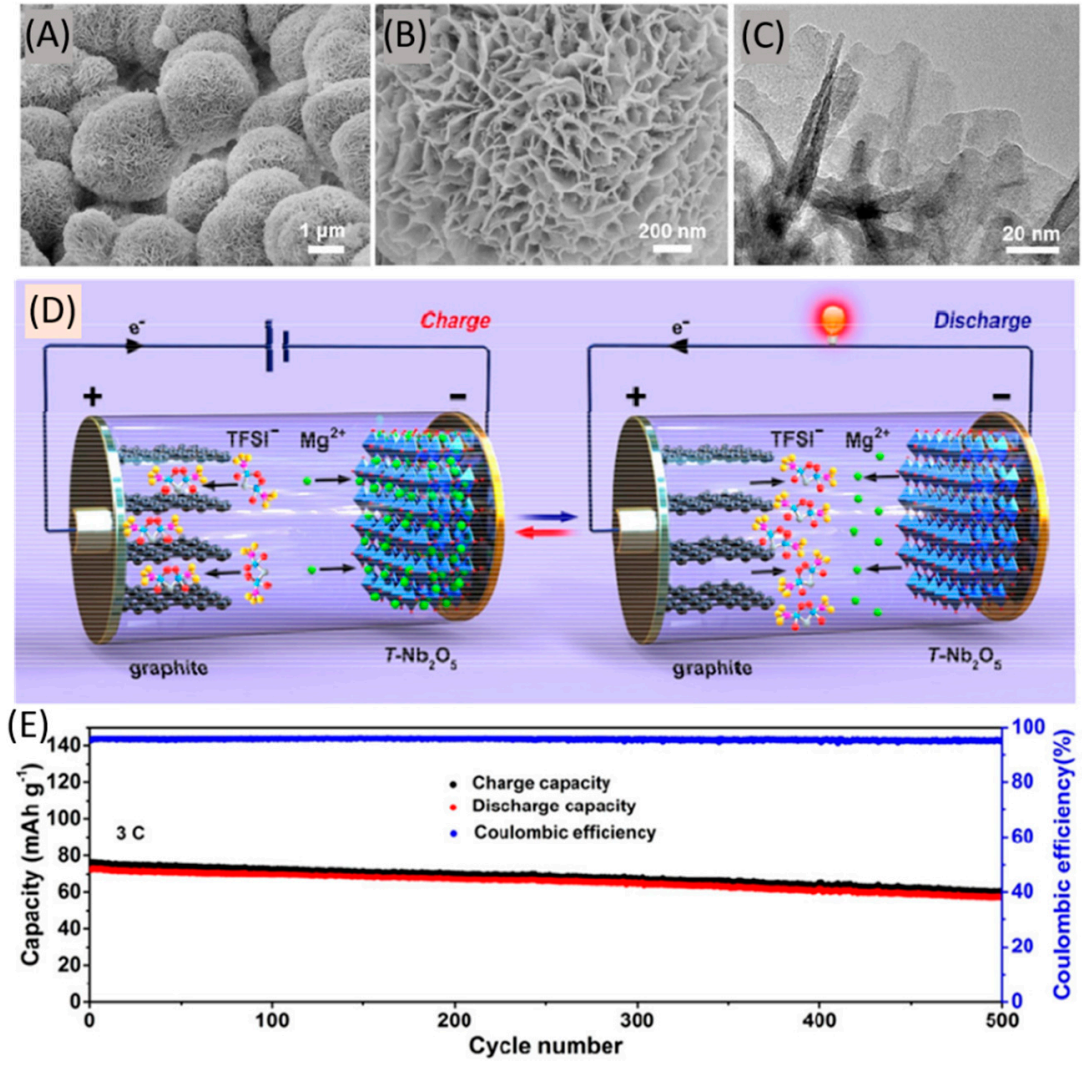

Figure 13. (A) Low- and (B) high-magnification SEM images and (C) TEM image of the $\mathrm{Ti}-\mathrm{Nb}_{2} \mathrm{O}_{5}$ NFs; (D) Operating principle of the magnesium-ion dual-ion battery and (E) its long-term cycling performance at $3 \mathrm{C}$ with $\mathrm{Ti}-\mathrm{Nb}_{2} \mathrm{O}_{5} \mathrm{NFs}$ as anode. Adapted with permission from [177]. Copyright American Chemical Society, 2020.

\subsection{Other Materials}

In this section, we list other metals (and related compounds) used in the last two years as anodes for MIBs. It is important to underline that also computational chemistry aims to predict new promising compounds as anodes for MIBs; some of these examples are discussed below.

Zhang et al. prepared $\mathrm{VO}_{2} \mathrm{NWs}$ by a conventional hydrothermal process [183]; their width was uniformly distributed around $100-300 \mathrm{~nm}$ and the length was equal to $\approx 10 \mu \mathrm{m}$ (Figure 14B). This electrode was first tested in a $\mathrm{MgSO}_{4} 1.0 \mathrm{M}$ aqueous electrolyte, showing initial charged capacities equal to 263, 207.7, 146.4 and $103 \mathrm{mAh} \mathrm{g}^{-1}$ at 100, 200, 500 and $1000 \mathrm{~mA} \mathrm{~g}^{-1}$, respectively. Conversely, performances in $\mathrm{MgCl}_{2}$ - and $\mathrm{Mg}\left(\mathrm{NO}_{3}\right)_{2}$-based electrolytes were rather poor, thus showing - again in the MIBs field-the relevant role of the magnesium salt for electrolyte formulation. As concerns prolonged charge/discharge experiments at $500 \mathrm{~mA} \mathrm{~g}{ }^{-1}$, the $\mathrm{VO}_{2} \mathrm{NWs}$ revealed a cycling stability of $54.3 \%$ after 100 cycles (Figure 14A); such an important fading was attributed to the partially irreversible reaction of magnesium ions (not being fully extracted from the host material lattice) and the partial dissolution of $\mathrm{VO}_{2}$ in the electrolyte upon time. Even improvements were required, the authors were able to follow the mechanism of the reaction by different characterization techniques. In detail, $\mathrm{VO}_{2}$ transformed into a stable $\mathrm{MgVO}_{\mathrm{x}}$ structure after the first charge, then the insertion/extraction of magnesium ions was accompanied by the valence changes of $\mathrm{V}^{5+}$ (reduced to $\mathrm{V}^{4+}$ ) and $\mathrm{V}^{4+}$ (reduced to $\mathrm{V}^{3+}$ ). 


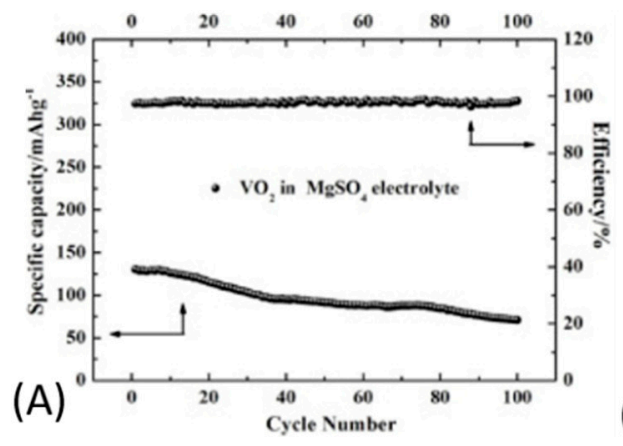

(B)
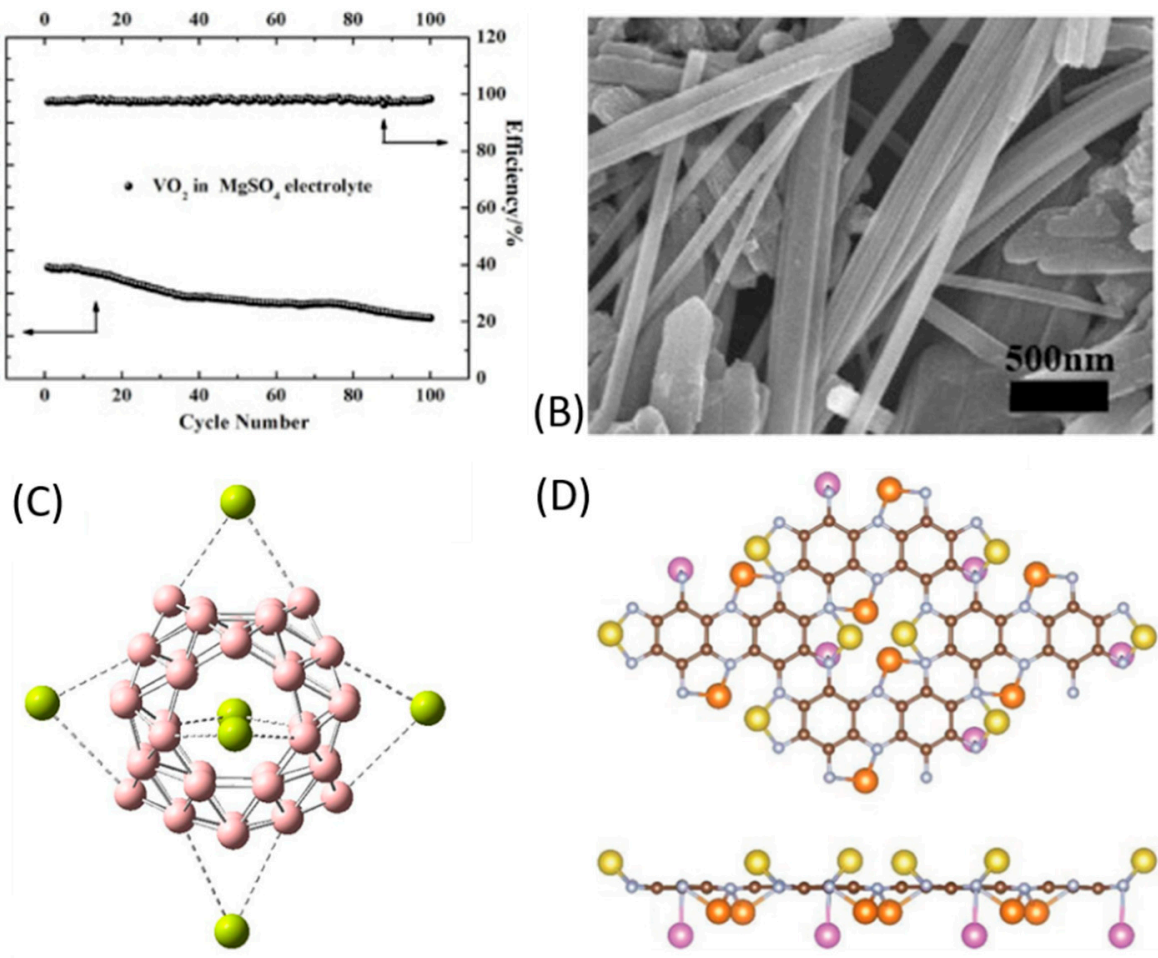

(D)

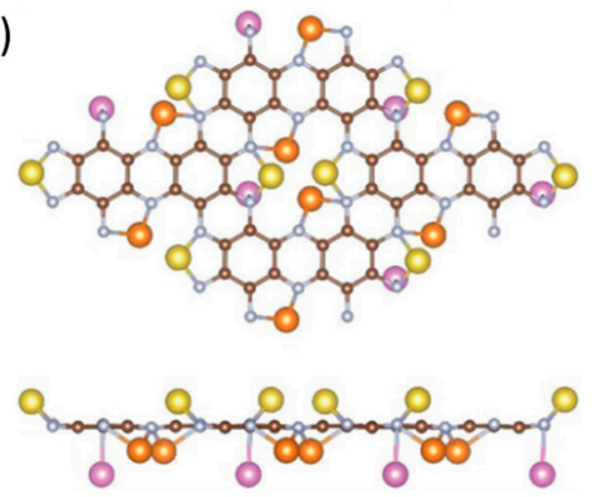

Figure 14. (A) Cycling properties of $\mathrm{VO}_{2} \mathrm{NWs}$ in $\mathrm{MgSO}_{4}$ electrolyte; (B) TEM micrograph of the anode before cycling; (C) Relaxed geometries of fully $\mathrm{Mg}$ decorated of bare and halide encapsulated $\mathrm{B}_{40}$ (B in pink, Mg in green); (D) Top and side views of the most stable configuration for five $\mathrm{Mg}$ atoms adsorption on a $\mathrm{C}_{2} \mathrm{~N}$ monolayer (yellow, orange and pink balls denote the $\mathrm{Mg}$ atoms located in the top, middle and bottom layers from the side view). Adapted with permission from [183-185]. Copyright Elsevier B.V. $(2019,2021)$ and Royal Society of Chemistry (2019).

Shakerzadeh et al. went through the latest outcomes in the field of boron clusters, among which the recently experimentally observed all-boron $\mathrm{B}_{40}$ fullerene with $\mathrm{D}_{2 d}$ symmetry is a stable allotrope. The authors set up DFT calculations to determine if $B_{40}$ fullerene could behave as an efficient anode for MIBs [184]. It emerged that the interactions between magnesium ions and heptagonal/hexagonal holes of $B_{40}$ fullerene were much stronger than those with magnesium metal. To calculate the performance of $B_{40}$ fullerene, its six holes were decorated with magnesium metal centres (Figure 14C), resulting in an open-circuit voltage and a storage capacity of $5.5 \mathrm{~V}$ and $744 \mathrm{mAh} \mathrm{g}^{-1}$, respectively. Surprisingly, it also emerged that halides (fluoride, chloride, bromide) encapsulation within $\mathrm{B}_{40}$ fullerene could markedly enhance the open-circuit voltage up to $8.8 \mathrm{~V}$. Overall, this study should push experimental scientists towards the preparation of boron-based anode materials for MIBs.

Theoretical investigations were also carried out to predict the fabrication of MIBs in stretchable configurations, in order to be employed in healthcare devices and sensors. In particular, Wu et al. worked on two-dimensional nitrogenated holey graphene $\left(\mathrm{C}_{2} \mathrm{~N}\right)$ anodes (Figure 14D) [185], predicting a maximum capacity and an open circuit voltage of $1175 \mathrm{mAh} \mathrm{g}^{-1}$ and $0.447 \mathrm{eV}$, respectively, in the strain-free state. The authors highlighted that the mechanical activation represents an effective strategy to boost charge redistribution and raising capacity values under tensile and compressive strains. Overall, it emerged that strains were able to remodulate- at the atomic scale-the structure of anodic materials, redistributing electrons in a uniform way and promoting the reactivation of adsorption sites. The stretchable device showed a two-stage diffusion mechanism: the out-of-plane magnesium ions diffused rapidly in the first stage, while in the following one the in-plane magnesium ions migrated moderately. Even if this study seems quite far from the traditional ones in the field of MIBs, it was precious to provide new insights on microscale mechanisms for stretchable energy storage devices, suggesting suitable structural requirements for bidimensional anodes. 
Several others anodic materials have been recently proposed and require further validation within the scientific community. Just to mention some of them, indium and lead were studied. After some experiments, indium has been judged inadequate due to high costs and low rate capability [186]; furthermore, an electrochemically driven amorphization of crystalline MgIn takes place when In is combined with $\mathrm{Pb}$ in solid solution [187]. Lead was excluded, even before considering the associated environmental issues and toxicity, because of the poor Coulombic efficiency [188]. The path ahead towards stable, efficient and cheap anodes for MIBs is still long, but the overall scenario towards large-scale energy systems able to store electricity from solar energy [189-192] is becoming feasible.

\section{Conclusions}

Despite the impressive properties shown by magnesium metal, its utilization as anode material has been shown to be unpractical mainly because of its very high sensitivity to surface reactions, which makes the choice of the electrolyte extremely difficult.

It is a matter of fact that, compared to the magnesium metal anode, all the ion insertion anodes cannot compete in terms of specific capacity; however, because of the problems caused by magnesium metal, their utilization seems to be necessary to conceive a commercial device. The main benefit brought by ion insertion anodes is the possibility to use conventional and well-known electrolytes that support reversible magnesium deposition. The cathode-side should also be taken into account, as it must be capable to reversibly work with the electrolyte solution.

Alternative anodes, allowing the utilization of a wider range of suitable electrolytes, ensure a better compatibility with cathodes. Moreover, as cathodes often represent the limiting factor in batteries, moving from magnesium metal anode to alternative anodic materials, with the associated loss of anodic specific capacity, may still result advantageous in terms of energy density of the whole device if oxide cathodes are used. Some materials, such as bismuth and tin, exhibited good properties like low reduction potentials and relatively high theoretical specific capacities, but currently they are far from being used in practical systems because of their poor electrochemical stability during prolonged cycling. Thus, dual-phase alloy anodes have been proposed by several groups as a possible solution and, in many cases, they showed superior properties if compared with both bismuth and tin separately, mainly thanks to better kinetics and the high reversibility that the double phase provides. Although the investigated dual-phase bismuth-tin alloys cannot be considered as a definitive solution, they anyway indicate an important field of research that may lead to the development of an advanced electrode material in the future.

Future perspectives in this field could pass through two materials classes that are leading to noteworthy results in the energy storage field. First, functionalized MXenes/graphene heterostructures could exhibit a great potential for magnesium ions intercalation, keeping at the same time a low interlayer expansion (and an overall reduction of geometric constraint). A second idea could be that of designing carbon-based anodes, following some strategies already developed for aqueous batteries; for example, carbon molecular sieve constructed by filling a carbon source into a sacrificial template could make use of the mesoporous tunnels of the template as a frame to host more magnesium ions.

Other important research fields to promote the development of MIBs (also targeting higher TRL levels) concern the preparation of chlorides-free electrolyte solutions with wide electrochemical windows, where magnesium can behave reversibly, and the elaboration of new cathodes, less sensitive to the composition of the electrolyte solutions. There is still much work to do towards the utilization of a clean and more efficient battery in order to support the ongoing worldwide energy transition. 
Funding: This research received no external funding.

Conflicts of Interest: The authors declare no conflict of interest.

\section{References}

1. Wunderling, N.; Willeit, M.; Donges, J.F.; Winkelmann, R. Global warming due to loss of large ice masses and Arctic summer sea ice. Nat. Commun. 2020, 11, 1-8. [CrossRef]

2. Guzmán, A.; Pinto-Gutiérrez, C.; Trujillo, M.A. Attention to global warming and the success of envi-ronmental initial coin offerings: Empirical evidence. Sustainability 2020, 12, 9885. [CrossRef]

3. Hari, V.; Rakovec, O.; Markonis, Y.; Hanel, M.; Kumar, R. Increased future occurrences of the exceptional 2018-2019 Central European drought under global warming. Sci. Rep. 2020, 10, 1-10. [CrossRef]

4. Kim, S.; Lee, J.E.; Kim, D. Searching for the Next New Energy in Energy Transition: Comparing the Impacts of Economic Incentives on Local Acceptance of Fossil Fuels, Renewable, and Nuclear Energies. Sustain. J. Rec. 2019, 11, 2037. [CrossRef]

5. Martins, F.; Felgueiras, C.; Smitkova, M.; Caetano, N. Analysis of Fossil Fuel Energy Consumption and Environmental Impacts in European Countries. Energies 2019, 12, 964. [CrossRef]

6. Hanif, I. Impact of fossil fuels energy consumption, energy policies, and urban sprawl on carbon emissions in East Asia and the Pacific: A panel investigation. Energy Strat. Rev. 2018, 21, 16-24. [CrossRef]

7. Chang, C.-L.; Ilomäki, J.; Laurila, H.; McAleer, M. Market timing with moving averages for fossil fuel and renewable energy stocks. Energy Rep. 2020, 6, 1798-1810. [CrossRef]

8. Zeppini, P.; Bergh, J.C.V.D. Global competition dynamics of fossil fuels and renewable energy under climate policies and peak oil: A behavioural model. Energy Policy 2020, 136, 110907. [CrossRef]

9. Brockway, P.E.; Owen, A.; Brand-Correa, L.I.; Hardt, L. Estimation of global final-stage ener-gy-return-on-investment for fossil fuels with comparison to renewable energy sources. Nat. Energy 2019, 4, 612-621. [CrossRef]

10. Saha, P.; Datta, M.K.; Velikokhatnyi, O.I.; Manivannan, A.; Alman, D.; Kumta, P.N. Rechargeable mag-nesium battery: Current status and key challenges for the future. Prog. Mater. Sci. 2014, 66, 1-86. [CrossRef]

11. Jithendranath, J.; Das, D.; Guerrero, J.M. Probabilistic optimal power flow in islanded microgrids with load, wind and solar uncertainties including intermittent generation spatial correlation. Energy 2021, 222, 119847. [CrossRef]

12. McCormick, P.G.; Suehrcke, H. The effect of intermittent solar radiation on the performance of PV sys-tems. Sol. Energy 2018, 171, 667-674. [CrossRef]

13. Piscitelli, M.S.; Brandi, S.; Capozzoli, A.; Xiao, F. A data analytics-based tool for the detection and di-agnosis of anomalous daily energy patterns in buildings. Build. Simul. 2021, 14, 131-147. [CrossRef]

14. Andersen, A.N.; Østergaard, P.A. Analytic versus solver-based calculated daily operations of district energy plants. Energy 2019, 175, 333-344. [CrossRef]

15. Esmaeili, A.; Nagadehi, S.S. Construction and optimization of polyethylene membrane with polyamides to remove pollutants and investigate their efficiency solar system. Int. J. Environ. Sci. Technol. 2020, 17, 3691-3704. [CrossRef]

16. Regalado-Pérez, E.; Mathews, N.; Mathew, X. Eu(III) complex-polymer composite luminescence down-shifting layers for reducing the blue-losses in thin film solar cells. Sol. Energy 2020, 199, 82-91. [CrossRef]

17. Zeng, Q.; Lai, Y.; Jiang, L.; Liu, F.; Hao, X.; Wang, L.; Green, M.A. Integrated Photorechargeable Energy Storage System: Next-Generation Power Source Driving the Future. Adv. Energy Mater. 2020, 10, 1903930. [CrossRef]

18. Latini, A.; Quaranta, S.; Menchini, F.; Lisi, N.; Di Girolamo, D.; Tarquini, O.; Colapietro, M.; Barba, L.; Demitri, N.; Cassetta, A. A novel water-resistant and thermally stable black lead halide perovskite, phenyl viologen lead iodide C22H18N2(PbI3)2. Dalton Trans. 2020, 49, 2616-2627. [CrossRef]

19. Ali, M.; Riaz, R.; Bae, S.; Lee, H.-S.; Jeong, S.H.; Ko, M.J. Layer-by-Layer Self-Assembly of Hollow Nitrogen-Doped Carbon Quantum Dots on Cationized Textured Crystalline Silicon Solar Cells for an Efficient Energy Down-Shift. ACS Appl. Mater. Interfaces 2020, 12, 10369-10381. [CrossRef]

20. Pulli, E.; Rozzi, E.; Bella, F. Transparent photovoltaic technologies: Current trends towards upscaling. Energy Convers. Manag. 2020, 219, 112982. [CrossRef]

21. Carella, A.; Centore, R.; Borbone, F.; Toscanesi, M.; Trifuoggi, M.; Bella, F.; Gerbaldi, C.; Galliano, S.; Schiavo, E.; Massaro, A.; et al. Tuning optical and electronic properties in novel carbazole photosensitizers for p-type dye-sensitized solar cells. Electrochim. Acta 2018, 292, 805-816. [CrossRef]

22. Bella, F.; Porcarelli, L.; Mantione, D.; Gerbaldi, C.; Barolo, C.; Grätzel, M.; Mecerreyes, D. A wa-ter-based and metal-free dye solar cell exceeding 7\% efficiency using a cationic poly(3,4-ethylenedioxythiophene) derivative. Chem. Sci. 2020, 11, 1485-1493. [CrossRef]

23. Ajaz, W.; Bernell, D. California's adoption of microgrids: A tale of symbiotic regimes and energy tran-sitions. Renew. Sustain. Energy Rev. 2021, 138, 110568. [CrossRef]

24. Wang, L.; Morabito, M.; Payne, C.T.; Robinson, G. Identifying institutional barriers and policy impli-cations for sustainable energy technology adoption among large organizations in California. Energy Policy 2020, 146, 111768. [CrossRef]

25. Patel, P.N. Developments in energy storage could spell the end of the duck curve. Power 2018, 162.

26. Radermacher, R. Building energy research and the "duck curve". Sci. Technol. Built Environ. 2017, 23, 1079. [CrossRef] 
27. California Independent System Operator. What the Duck Curve Tells Us about Managing a Green Grid. 2013. Available online: http:/ / large.stanford.edu/courses/2015/ph240/burnett2/docs/flexible.pdf (accessed on 1 February 2021).

28. Burnett, M. Energy Storage and the California "Duck Curve". 2016. Available online: http://large.stanford.edu/courses/2015 /ph240/burnett2/ (accessed on 1 February 2021).

29. IFP Energies Nouvelles, Quelle Criticité du Lithium Dans un Contexte D'électrification du Parc Automobile Mondial? 2018. Available online: https:/ / www.ifpenergiesnouvelles.fr/article/quelle-criticite-du-lithium-contexte-delectrification-du-parcautomobile-mondial (accessed on 1 February 2021).

30. Fagiolari, L.; Bonomo, M.; Cognetti, A.; Meligrana, G.; Gerbaldi, C.; Barolo, C.; Bella, F. Photoanodes for Aqueous Solar Cells: Exploring Additives and Formulations Starting from a Commercial TiO 2 Paste. ChemSusChem 2020, 13, 6562-6573. [CrossRef]

31. Baiano, C.; Schiavo, E.; Gerbaldi, C.; Bella, F.; Meligrana, G.; Talarico, G.; Maddalena, P.; Pavone, M.; Muñoz-García, A.B. Role of surface defects in $\mathrm{CO} 2$ adsorption and activation on $\mathrm{CuFeO} 2$ delafossite oxide. Mol. Catal. 2020, 496, 111181. [CrossRef]

32. Mariotti, N.; Bonomo, M.; Fagiolari, L.; Barbero, N.; Gerbaldi, C.; Bella, F.; Barolo, C. Recent advances in eco-friendly and cost-effective materials towards sustainable dye-sensitized solar cells. Green Chem. 2020, 22, 7168-7218. [CrossRef]

33. Galliano, S.; Bella, F.; Bonomo, M.; Viscardi, G.; Gerbaldi, C.; Boschloo, G.; Barolo, C. Hydrogel Electrolytes Based on Xanthan Gum: Green Route Towards Stable Dye-Sensitized Solar Cells. Nanomaterials 2020, 10, 1585. [CrossRef]

34. Dokouzis, A.; Bella, F.; Theodosiou, K.; Gerbaldi, C.; Leftheriotis, G. Photoelectrochromic devices with cobalt redox electrolytes. Mater. Today Energy 2020, 15, 100365. [CrossRef]

35. Kim, Y.-J.; Jin, H.S.; Lee, D.-H.; Choi, J.; Jo, W.; Noh, H.; Lee, J.; Chu, H.; Kwack, H.; Ye, F.; et al. Guided Lithium Deposition by Surface Micro-Patterning of Lithium-Metal Electrodes. ChemElectroChem 2018, 5, 3169-3175. [CrossRef]

36. Zhang, T.; Yang, L.; Yan, X.; Ding, X. Recent Advances of Cellulose-Based Materials and Their Promising Application in Sodium-Ion Batteries and Capacitors. Small 2018, 14, e1802444. [CrossRef]

37. Kim, J.I.; Chung, K.Y.; Park, J.H. Design of a porous gel polymer electrolyte for sodium ion batteries. J. Membr. Sci. 2018, 566, 122-128. [CrossRef]

38. Wang, S.; Liu, X.; Wang, A.; Wang, Z.; Chen, J.; Zeng, Q.; Wang, X.; Zhang, L. An ionic liquid crystal-based solid polymer electrolyte with desirable ion-conducting channels for superior performance ambient-temperature lithium batteries. Polym. Chem. 2018, 9, 4674-4682. [CrossRef]

39. Singh, S.; Arora, N.; Paul, K.; Kumar, R.; Kumar, R. FTIR and rheological studies of PMMA-based nano-dispersed gel polymer electrolytes incorporated with LiBF4 and SiO2. Ionics 2018, 25, 1495-1503. [CrossRef]

40. Wafi, N.I.B.; Daud, W.R.W.; Ahmad, A.; Majlan, E.H.; Somalu, M.R. Effect of lithium hexafluorophosphate LiPF6 and 1-butyl3-methylimidazolium bis(trifluoromethanesulfonyl)imide [Bmim][TFSI] immobilized in poly(2-hydroxyethyl methacrylate) PHEMA. Polym. Bull. 2018, 76, 3693-3707. [CrossRef]

41. Mukkabla, R.; Killi, K.; Shivaprasad, S.M.; Deepa, M. Metal oxide interlayer for long-lived lithium-selenium batteries. Chem. Eur. J. 2018, 24, 17327-17338. [CrossRef] [PubMed]

42. Zhang, H.; Zhao, H.; Khan, M.A.; Zou, W.; Xu, J.; Zhang, L.; Zhang, J. Recent progress in advanced electrode materials, separators and electrolytes for lithium batteries. J. Mater. Chem. A 2018, 6, 20564-20620. [CrossRef]

43. Ma, Q.; Chakrabarti, A.; Mei, X.; Yue, Z.; Dunya, H.; Filler, R.; Mandal, B.K. New oligoether plasticizers for poly(ethylene oxide)-based solid polymer electrolytes. Ionics 2018, 25, 1633-1643. [CrossRef]

44. Shan, L.; Yurong, C.; Jing, Y.; Feixia, R.; Jun, W.; Babu, S.; Xin, Y.; Junkuo, G.; Juming, Y. Entrapment of polysulfides by a Ketjen Black \& mesoporous TiO2 modified glass fiber separator for high performance lithium-sulfur batteries. J. Alloy. Compd. 2019, 779, 412-419. [CrossRef]

45. Liu, T.; Sun, X.; Sun, S.; Niu, Q.; Liu, H.; Song, W.; Cao, F.; Li, X.; Ohsaka, T.; Wu, J. A robust and low-cost biomass carbon fiber@SiO2 interlayer for reliable lithium-sulfur batteries. Electrochim. Acta 2019, 295, 684-692. [CrossRef]

46. Zhou, B.; Zuo, C.; Xiao, Z.; Zhou, X.; He, D.; Xie, X.; Xue, Z. Self-Healing Polymer Electrolytes Formed via Dual-Networks: A New Strategy for Flexible Lithium Metal Batteries. Chem. A Eur. J. 2018, 24, 19200-19207. [CrossRef]

47. Chen, Y.; Xu, G.; Liu, X.; Pan, Q.; Zhang, Y.; Zeng, D.; Sun, Y.; Ke, H.; Cheng, H. A gel single ion conducting polymer electrolyte enables durable and safe lithium ion batteries via graft polymerization. RSC Adv. 2018, 8, 39967-39975. [CrossRef]

48. Cho, S.; Kim, S.; Kim, W.; Kim, S.; Ahn, S. All-solid-state lithium batteryworking without an additional separator in a polymeric electrolyte. Polymers 2018, 10, 1364. [CrossRef]

49. Lu, Q.; Fu, J.; Chen, L.; Shang, D.; Li, M.; Xu, Y.; Jia, R.; Yuan, S.; Shi, L. Polymeric polyhedral oligomeric silsesquioxane ionic liquids based solid polymer electrolytes for lithium ion batteries. J. Power Sources 2019, 414, 31-40. [CrossRef]

50. Liu, R.; Wu, Z.; He, P.; Fan, H.; Huang, Z.; Zhang, L.; Chang, X.; Liu, H.; Wang, C.-A.; Li, Y. A self-standing, UV-cured semi-interpenetrating polymer network reinforced composite gel electrolytes for dendrite-suppressing lithium ion batteries. J. Materiomics 2019, 5, 185-194. [CrossRef]

51. Dixit, A.; Middya, S.; Mitra, S.; Maity, S.; Bhattacharjee, M.; Bandyopadhyay, D. Unexplored Pathways To Charge Storage in Supercapacitors. J. Phys. Chem. C 2018, 123, 195-204. [CrossRef]

52. Xiao, Q.; Deng, C.; Wang, Q.; Zhang, Q.; Yue, Y.; Ren, S. In Situ Cross-Linked Gel Polymer Electrolyte Membranes with Excellent Thermal Stability for Lithium Ion Batteries. ACS Omega 2019, 4, 95-103. [CrossRef]

53. Chen, S.; Feng, F.; Yin, Y.; Lizo, X.; Ma, Z. Plastic crystal polymer electrolytes containing boron based anion acceptors for room temperature all-solid-state sodium-ion batteries. Energy Storage Mater. 2019, 22, 57-65. [CrossRef] 
54. Wu, N.; Qiao, X.; Shen, J.; Liu, G.; Sun, T.; Wu, H.; Hou, H.; Liu, X.; Zhang, Y.; Ji, X. Anatase inverse opal TiO2-x@N-doped C induced the dominant pseudocapacitive effect for durable and fast lithium/sodium storage. Electrochim. Acta 2019, 299, 540-548. [CrossRef]

55. Siahroodi, H.J.; Mojallali, H.; Mohtavipour, S.S. Scenario-based stochastic framework for harmonic power markets using plug-in electric vehicles. J. Energy Storage 2021, 35, 102290. [CrossRef]

56. Ardeshiri, A.; Rashidi, T.H. Willingness to pay for fast charging station for electric vehicles with limited market penetration making. Energy Policy 2020, 147, 111822. [CrossRef]

57. Gong, B.; Liu, R.; Zhang, X. Market acceptability assessment of electric vehicles based on an improved stochastic multicriteria acceptability analysis-evidential reasoning approach. J. Clean. Prod. 2020, 269, 121990. [CrossRef]

58. Cho, J.; Jeong, S.; Kim, Y. Commercial and research battery technologies for electrical energy storage applications. Prog. Energy Combust. Sci. 2015, 48, 84-101. [CrossRef]

59. Koohi-Fayegh, S.; Rosen, M. A review of energy storage types, applications and recent developments. J. Energy Storage 2020, 27, 101047. [CrossRef]

60. Akinyele, D.; Belikov, J.; Levron, Y. Battery Storage Technologies for Electrical Applications: Impact in Stand-Alone Photovoltaic Systems. Energies 2017, 10, 1760. [CrossRef]

61. Yuan, B.; Luo, G.; Liang, J.; Cheng, F.; Zhang, W.; Chen, J. Self-assembly synthesis of solid polymer electrolyte with carbonate terminated poly(ethylene glycol) matrix and its application for solid state lithium battery. J. Energy Chem. 2019, 38, 55-59. [CrossRef]

62. Nie, K.; Hong, Y.; Qiu, J.; Li, Q.; Yu, X.; Li, H.; Chen, L. Interfaces Between Cathode and Electrolyte in Solid State Lithium Batteries: Challenges and Perspectives. Front. Chem. 2018, 6, 616. [CrossRef]

63. Fei, Y.; Liu, S.; Long, Y.; Lu, L.; He, Y.; Ma, X.; Deng, Y. New single lithium ion conducting polymer electrolyte derived from delocalized tetrazolate bonding to polyurethane. Electrochim. Acta 2019, 299, 902-913. [CrossRef]

64. Jeong, K.; Park, S.; Lee, S.-Y. Revisiting polymeric single lithium-ion conductors as an organic route for all-solid-state lithium ion and metal batteries. J. Mater. Chem. A 2018, 7, 1917-1935. [CrossRef]

65. Banitaba, S.N.; Semnani, D.; Rezaei, B.; Ensafi, A.A. Evaluating the electrochemical properties of PEO-based nanofibrous electrolytes incorporated with TiO2nanofiller applicable in lithium-ion batteries. Polym. Adv. Technol. 2019, 30, 1234-1242. [CrossRef]

66. Huang, S.; Cui, Z.; Qiao, L.; Xu, G.; Zhang, J.; Tang, K.; Liu, X.; Wang, Q.; Zhou, X.; Zhang, B.; et al. An in-situ polymerized solid polymer electrolyte enables excellent interfacial compatibility in lithium batteries. Electrochim. Acta 2019, 299, 820-827. [CrossRef]

67. Ma, L.; Fu, C.; Li, L.; Mayilvahanan, K.S.; Watkins, T.; Perdue, B.R.; Zavadil, K.R.; Helms, B.A. Nanoporous Polymer Films with a High Cation Transference Number Stabilize Lithium Metal Anodes in Light-Weight Batteries for Electrified Transportation. Nano Lett. 2019, 19, 1387-1394. [CrossRef]

68. Hadjichristov, G.B.; Ivanov, T.E.; Marinov, Y.G.; Koduru, H.K.; Scaramuzza, N. PEO-PVP-NaIO4 ion-conducting polymer electrolyte: Inspection for ionic space charge polarization and charge trapping. Phys. Status Solidi A 2019, 216, 1800739. [CrossRef]

69. Froboese, L.; Van Der Sichel, J.F.; Loellhoeffel, T.; Helmers, L.; Kwade, A. Effect of Microstructure on the Ionic Conductivity of an All Solid-State Battery Electrode. J. Electrochem. Soc. 2019, 166, A318-A328. [CrossRef]

70. Li, K.; Zhang, J.; Lin, D.; Wang, D.W.; Li, B.; Lv, W.; Sun, S.; He, Y.B.; Kang, F.; Yang, Q.H.; et al. Evolution of the electrochemical interface in sodium ion batteries with ether electrolytes. Nat. Commun. 2019, 10, 725. [CrossRef]

71. Mohtadi, R.; Mizuno, F. Magnesium batteries: Current state of the art, issues and future perspectives. Beilstein J. Nanotechnol. 2014, 5, 1291-1311. [CrossRef]

72. Munoz, S.; Greenbaum, S. Review of Recent Nuclear Magnetic Resonance Studies of Ion Transport in Polymer Electrolytes. Membranes 2018, 8, 120. [CrossRef]

73. Saadiah, M.; Zhang, D.; Nagao, Y.; Muzakir, S.; Samsudin, A. Reducing crystallinity on thin film based CMC/PVA hybrid polymer for application as a host in polymer electrolytes. J. Non-Crystalline Solids 2019, 511, 201-211. [CrossRef]

74. Qiu, Z.; Shi, L.; Wang, Z.; Mindemark, J.; Zhu, J.; Edström, K.; Zhao, Y.; Yuan, S. Surface activated polyethylene separator promoting $\mathrm{Li}+$ ion transport in gel polymer electrolytes and cycling stability of Li-metal anode. Chem. Eng. J. 2019, 368, 321-330. [CrossRef]

75. Lin, L.; Lei, W.; Zhang, S.; Liu, Y.; Wallace, G.G.; Chen, J. Two-dimensional transition metal dichalcogenides in supercapacitors and secondary batteries. Energy Storage Mater. 2019, 19, 408-423. [CrossRef]

76. Ma, F.; Zhang, Z.-Q.; Yan, W.; Ma, X.; Sun, D.; Jin, Y.; Chen, X.; He, K. Solid Polymer Electrolyte Based on Polymerized Ionic Liquid for High Performance All-Solid-State Lithium-Ion Batteries. ACS Sustain. Chem. Eng. 2019, 7, 4675-4683. [CrossRef]

77. Rosendahl, K.E.; Rubiano, D.R. How effective is lithium recycling as a remedy for resource scarcity? Environ. Resour. Econ. 2019, 74, 985-1010. [CrossRef]

78. Calisaya-Azpilcueta, D.; Herrera-Leon, S.; Lucay, F.A.; Cisternas, L.A. Assessment of the Supply Chain under Uncertainty: The Case of Lithium. Minerals 2020, 10, 604. [CrossRef]

79. Schiavi, P.G.; Altimari, P.; Zanoni, R.; Pagnanelli, F. Full recycling of spent lithium ion batteries with production of core-shell nanowires//exfoliated graphite asymmetric supercapacitor. J. Energy Chem. 2021, 58, 336-344. [CrossRef]

80. Bustos-Gallardo, B.; Bridge, G.; Prieto, M. Harvesting Lithium: Water, brine and the industrial dynamics of production in the Salar de Atacama. Geoforum 2021, 119, 177-189. [CrossRef] 
81. Kosai, S.; Takata, U.; Yamasue, E. Natural resource use of a traction lithium-ion battery production based on land disturbances through mining activities. J. Clean. Prod. 2021, 280, 124871. [CrossRef]

82. Zhang, Y.; Lu, W.; Cong, L.; Liu, J.; Sun, L.; Mauger, A.; Julien, C.M.; Xie, H.; Liu, J. Cross-linking network based on Poly(ethylene oxide): Solid polymer electrolyte for room temperature lithium battery. J. Power Sources 2019, 420, 63-72. [CrossRef]

83. Forsyth, M.; Porcarelli, L.; Wang, X.; Goujon, N.; Mecerreyes, D. Innovative Electrolytes Based on Ionic Liquids and Polymers for Next-Generation Solid-State Batteries. Accounts Chem. Res. 2019, 52, 686-694. [CrossRef]

84. Patel, S.; Kumar, R. Synthesis and characterization of magnesium ion conductivity in PVDF based nanocomposite polymer electrolytes disperse with MgO. J. Alloys Compd. 2019, 789, 6-14. [CrossRef]

85. Zhu, Y.; Cao, J.; Chen, H.; Yu, Q.; Li, B. High electrochemical stability of a 3D cross-linked network PEO@nano-SiO2 composite polymer electrolyte for lithium metal batteries. J. Mater. Chem. A 2019, 7, 6832-6839. [CrossRef]

86. Edison Investment Research Limited. Available online: https://www.youtube.com/watch?v=rQ6U5DtxEOw (accessed on 1 February 2021).

87. Xu, J.; Dou, S.; Cui, X.; Liu, W.; Zhang, Z.; Deng, Y.; Hu, W.; Chen, Y. Potassium-based electro-chemical energy storage devices: Development status and future prospect. Energy Storage Mater. 2021, 34, 85-106. [CrossRef]

88. Zhou, M.; Bai, P.; Ji, X.; Yang, J.; Wang, C.; Xu, Y. Electrolytes and Interphases in Potassium Ion Batteries. Adv. Mater. 2021, 33, e2003741. [CrossRef]

89. Jin, T.; Han, Q.; Jiao, L. Binder-free electrodes for advanced sodium-ion batteries. Adv. Mater. 2020, 32, 1806304. [CrossRef]

90. Huang, Y.; Zhao, L.; Li, L.; Xie, M.; Wu, F.; Chen, R. Electrolytes and Electrolyte/Electrode Interfaces in Sodium-Ion Batteries: From Scientific Research to Practical Application. Adv. Mater. 2019, 31, e1808393. [CrossRef]

91. Sångeland, C.; Younesi, R.; Mindemark, J.; Brandell, D. Towards room temperature operation of all-solid-state Na-ion batteries through polyester-polycarbonate-based polymer electrolytes. Energy Storage Mater. 2019, 19, 31-38. [CrossRef]

92. Guo, Q.; Zeng, W.; Liu, S.-L.; Li, Y.-Q.; Xu, J.-Y.; Wang, J.-X.; Wang, Y. Recent developments on anode materials for magnesium-ion batteries: A review. Rare Met. 2021, 40, 290-308. [CrossRef]

93. Pei, C.; Xiong, F.; Yin, Y.; Liu, Z.; Tang, H.; Sun, R.; An, Q.; Mai, L. Recent Progress and Challenges in the Optimization of Electrode Materials for Rechargeable Magnesium Batteries. Small 2021, 17, e2004108. [CrossRef]

94. Liu, F.; Wang, T.; Liu, X.; Fan, L. Challenges and Recent Progress on Key Materials for Rechargeable Magnesium Batteries. Adv. Energy Mater. 2021, 11, 2000787. [CrossRef]

95. You, C.; Wu, X.; Yuan, X.; Chen, Y.; Liu, L.; Zhu, Y.; Fu, L.; Wu, Y.; Guo, Y.-G.; Van Ree, T. Advances in rechargeable Mg batteries. J. Mater. Chem. A 2020, 8, 25601-25625. [CrossRef]

96. Li, D.; Yuan, Y.; Liu, J.; Fichtner, M.; Pan, F. A review on current anode materials for rechargeable Mg batteries. J. Magnes. Alloy. 2020, 8, 963-979. [CrossRef]

97. Shi, J.; Zhang, J.; Guo, J.; Lu, J. Interfaces in rechargeable magnesium batteries. Nanoscale Horizons 2020, 5, 1467-1475. [CrossRef]

98. Shuai, H.; Xu, J.; Huang, K. Progress in retrospect of electrolytes for secondary magnesium batteries. Co-ord. Chem. Rev. 2020, 422, 213478. [CrossRef]

99. Rubio, S.; Medina, A.; Cabello, M.; LaVela, P.; Alcántara, R.; Vicente, C.P.; Ortiz, G.F.; Tirado, J.L. Inorganic solids for dual magnesium and sodium battery electrodes. J. Solid State Electrochem. 2020, 24, 1-9. [CrossRef]

100. Tan, S.; Xiong, F.; Wang, J.; An, Q.; Mai, L. Crystal regulation towards rechargeable magnesium battery cathode materials. Mater. Horizons 2020, 7, 1971-1995. [CrossRef]

101. Niu, J.; Zhang, Z.; Aurbach, D. Alloy Anode Materials for Rechargeable Mg Ion Batteries. Adv. Energy Mater. 2020, 10, 2000697. [CrossRef]

102. Yoo, H.D.; Shterenberg, I.; Gofer, Y.; Gershinsky, G.; Pour, N.; Aurbach, D. Mg rechargeable batteries: An on-going challenge. Energy Environ. Sci. 2013, 6, 2265-2279. [CrossRef]

103. Aurbach, D.; Weissman, I.; Gofer, Y.; Levi, E. Nonaqueous magnesium electrochemistry and its appli-cation in secondary batteries. Chem. Rec. 2003, 3, 61-73. [CrossRef]

104. Castelletti, M. Verso la Fine dell'Economia: Apice e Collasso del Consumismo; Fuoco Edizioni: Rome, Italy, 2013.

105. Guo, Z.; Zhao, S.; Li, T.; Su, D.; Guo, S.; Wang, G. Recent Advances in Rechargeable Magnesium-Based Batteries for High-Efficiency Energy Storage. Adv. Energy Mater. 2020, 10, 1903591. [CrossRef]

106. Anderson, D.L. Chemical composition of the mantle. J. Geophys. Res. Space Phys. 1983, 88, B41-B52. [CrossRef]

107. Witte, F. The history of biodegradable magnesium implants: A review. Acta Biomater. 2010, 6, 1680-1692. [CrossRef]

108. Ehrenberger, S.; Friedrich, H.E. Life-cycle assessment of the recycling of magnesium vehicle compo-nents. JOM 2013, 65, 1303-1309. [CrossRef]

109. UNEP. Recycling Rates of Metals. 2011. Available online: www.unep.org (accessed on 1 February 2021).

110. Attias, R.; Salama, M.; Hirsch, B.; Goffer, Y.; Aurbach, D. Anode-Electrolyte Interfaces in Secondary Magnesium Batteries. Joule 2019, 3, 27-52. [CrossRef]

111. Shimokawa, K.; Ichitsubo, T. Spinel-rocksalt transition as a key cathode reaction toward high-energy-density magnesium rechargeable batteries. Curr. Opin. Electrochem. 2020, 21, 93-99. [CrossRef]

112. Park, B.; Schaefer, J.L. Review-polymer electrolytes for magnesium batteries: Forging away from ana-logs of lithium polymer electrolytes and towards the rechargeable magnesium metal polymer battery. J. Electrochem. Soc. 2020, 167, 070545. [CrossRef] 
113. Deivanayagam, R.; Ingram, B.J.; Shahbazian-Yassar, R. Progress in development of electrolytes for magnesium batteries. Energy Storage Mater. 2019, 21, 136-153. [CrossRef]

114. Li, Z.; Han, L.; Wang, Y.; Li, X.; Lu, J.; Hu, X. Microstructure Characteristics of Cathode Materials for Rechargeable Magnesium Batteries. Small 2019, 15, e1900105. [CrossRef]

115. Li, G.; Huang, B.; Pan, Z.; Su, X.; Shao, Z.; An, L. Advances in three-dimensional graphene-based ma-terials: Configurations, preparation and application in secondary metal ( $\mathrm{Li}, \mathrm{Na}, \mathrm{K}, \mathrm{Mg}, \mathrm{Al})$-ion batteries. Energy Environ. Sci. 2019, 12, 2030-2053. [CrossRef]

116. Zhang, Y.; Geng, H.; Wei, W.; Ma, J.; Chen, L.; Li, C.C. Challenges and recent progress in the design of advanced electrode materials for rechargeable Mg batteries. Energy Storage Mater. 2019, 20, 118-138. [CrossRef]

117. Zhao-Karger, Z.; Fichtner, M. Beyond Intercalation Chemistry for Rechargeable Mg Batteries: A Short Review and Perspective. Front. Chem. 2019, 6, 656. [CrossRef]

118. Li, L.; Lu, Y.; Zhang, Q.; Zhao, S.; Hu, Z.; Chou, S. Recent Progress on Layered Cathode Materials for Nonaqueous Rechargeable Magnesium Batteries. Small 2021, 17, e1902767. [CrossRef]

119. Muldoon, J.; Bucur, C.B.; Gregory, T. Fervent hype behind magnesium batteries: An open call to syn-thetic chemists-electrolytes and cathodes needed. Angew. Chem. Int. Ed. 2017, 56, 12064-12084. [CrossRef] [PubMed]

120. He, S.; Nielson, K.V.; Luo, J.; Liu, T.L. Recent advances on $\mathrm{MgCl} 2$ based electrolytes for rechargeable Mg batteries. Energy Storage Mater. 2017, 8, 184-188. [CrossRef]

121. Park, M.-S.; Kim, J.-G.; Kim, Y.-J.; Choi, N.-S.; Kim, J.-S. Recent Advances in Rechargeable Magnesium Battery Technology: A Review of the Field's Current Status and Prospects. Isr. J. Chem. 2015, 55, 570-585. [CrossRef]

122. Muldoon, J.; Bucur, C.B.; Gregory, T. Quest for nonaqueous multivalent secondary batteries: Magne-sium and beyond. Chem. Rev. 2014, 114, 11683-11720. [CrossRef] [PubMed]

123. Lu, Z.; Schechter, A.; Moshkovich, M.; Aurbach, D. On the electrochemical behavior of magnesium electrodes in polar aprotic electrolyte solutions. J. Electroanal. Chem. 1999, 466, 203-217. [CrossRef]

124. Zhou, X.; Luo, X.; Wang, H.; Yang, J.; Xu, H.; Jia, M.; Tang, J. Reduced graphene oxide@CoSe2 interlayer as anchor of polysulfides for high properties of lithium-sulfur battery. J. Mater. Sci. 2019, 54, 9622-9631. [CrossRef]

125. Xiaoman, L.; Qinglin, Z.; Weimin, G.; Qinghua, L. The catalytic activity of manganese dioxide supported on graphene promoting the electrochemical performance of lithium-sulfur batteries. J. Electroanal. Chem. 2019, 840, 144-152. [CrossRef]

126. Wang, Z.; Chen, S.; Huang, Z.; Wei, Z.; Shen, L.; Gu, H.; Xu, X.; Yao, X. High conductivity polymer electrolyte with comb-like structure via a solvent-free UV-cured method for large-area ambient all-solid-sate lithium batteries. J. Materiomics 2019, 5, 195-203. [CrossRef]

127. Ding, Y.; Sun, J.; Liu, X. Carbon-decorated flower-like ZnO as high-performance anode materials for Li-ion batteries. Ionics 2019, 25, 4129-4136. [CrossRef]

128. Delaporte, N.; Guerfi, A.; Demers, H.; Lorrmann, H.; Paolella, A.; Zaghib, K. Facile protection of lithium metal for all-solid-state batteries. ChemistryOpen 2019, 8, 192-195. [CrossRef]

129. Kim, H.; Jeong, G.; Kim, Y.-U.; Kim, J.-H.; Park, C.-M.; Sohn, H.-J. Metallic anodes for next generation secondary batteries. Chem. Soc. Rev. 2013, 42, 9011-9034. [CrossRef]

130. Falco, M.; Simari, C.; Ferrara, C.; Nair, J.R.; Meligrana, G.; Bella, F.; Nicotera, I.; Mustarelli, P.; Winter, M.; Gerbaldi, C. Understanding the effect of UV-induced cross-linking on the physicochemical properties of highly performing PEO/LiTFSI-based polymer electrolytes. Langmuir 2019, 35, 8210-8219. [CrossRef]

131. Piana, G.; Ricciardi, M.; Bella, F.; Cucciniello, R.; Proto, A.; Gerbaldi, C. Poly(glycidyl ether)s recy-cling from industrial waste and feasibility study of reuse as electrolytes in sodium-based batteries. Chem. Eng. J. 2020, 382, 122934. [CrossRef]

132. Piana, G.; Bella, F.; Geobaldo, F.; Meligrana, G.; Gerbaldi, C. PEO/LAGP hybrid solid polymer elec-trolytes for ambient temperature lithium batteries by solvent-free, "one pot" preparation. J. Energy Storage 2019, 26, 100947. [CrossRef]

133. Falco, M.; Castro, L.; Nair, J.R.; Bella, F.; Bardé, F.; Meligrana, G.; Gerbaldi, C. UV-Cross-Linked Composite Polymer Electrolyte for High-Rate, Ambient Temperature Lithium Batteries. ACS Appl. Energy Mater. 2019, 2, 1600-1607. [CrossRef]

134. Ouhib, F.; Meabe, L.; Mahmoud, A.; Eshraghi, N.; Grignard, B.; Thomassin, J.-M.; Aqil, A.; Boschini, F.; Jerome, C.; Mecerreyes, D.; et al. CO2-sourced polycarbonates as solid electrolytes for room temperature operating lithium batteries. J. Mater. Chem. A 2019, 7, 9844-9853. [CrossRef]

135. Wu, Z.; Xie, Z.; Yoshida, A.; Wang, Z.; Hao, X.; Abudula, A.; Guan, G. Utmost limits of various solid electrolytes in all-solid-state lithium batteries: A critical review. Renew. Sustain. Energy Rev. 2019, 109, 367-385. [CrossRef]

136. Zhang, B.; Zhang, Y.; Zhang, N.; Liu, J.; Cong, L.; Liu, J.; Sun, L.; Mauger, A.; Julien, C.M.; Xie, H.; et al. Synthesis and interface stability of polystyrene-poly(ethylene glycol)-polystyrene triblock copolymer as solid-state electrolyte for lithium-metal batteries. J. Power Sources 2019, 428, 93-104. [CrossRef]

137. Son, J.; Oh, S.; Bae, S.; Nam, S.; Oh, I. A Pair of NiCo 2 O 4 and V 2 O 5 Nanowires Directly Grown on Carbon Fabric for Highly Bendable Lithium-Ion Batteries. Adv. Energy Mater. 2019, 9, 1900477. [CrossRef] 
138. Li, J.; Chen, H.; Shen, Y.; Hu, C.; Cheng, Z.; Lu, W.; Qiu, Y.; Chen, L. Covalent interfacial coupling for hybrid solid-state Li ion conductor. Energy Storage Mater. 2019, 23, 277-283. [CrossRef]

139. Wang, M.; Yagi, S. Redox behavior of VS2 nanosheets in Grignard reagent-based electrolyte. Mater. Lett. 2020, $273,127914$. [CrossRef]

140. Lee, B.; Cho, J.H.; Seo, H.R.; Na, S.B.; Kim, J.H.; Cho, B.W.; Yim, T.; Oh, S.H. Strategic combination of Grignard reagents and allyl-functionalized ionic liquids as an advanced electrolyte for rechargeable mag-nesium batteries. J. Mater. Chem. A 2018, 6, 3126-3133. [CrossRef]

141. Pedico, A.; Lamberti, A.; Gigot, A.; Fontana, M.; Bella, F.; Rivolo, P.; Cocuzza, M.; Pirri, C.F. High-Performing and Stable Wearable Supercapacitor Exploiting rGO Aerogel Decorated with Copper and Molybdenum Sulfides on Carbon Fibers. ACS Appl. Energy Mater. 2018, 1, 4440-4447. [CrossRef]

142. Nair, J.R.; Colò, F.; Kazzazi, A.; Moreno, M.; Bresser, D.; Lin, R.; Bella, F.; Meligrana, G.; Fantini, S.; Simonetti, E.; et al. Room temperature ionic liquid (RTIL)-based electrolyte cocktails for safe, high working potential Li-based polymer batteries. J. Power Sources 2019, 412, 398-407. [CrossRef]

143. Radzir, N.N.M.; Abu Hanifah, S.; Ahmad, A.; Hassan, N.H.; Bella, F. Effect of lithium bis(trifluoromethylsulfonyl)imide salt-doped UV-cured glycidyl methacrylate. J. Solid State Electrochem. 2015, 19, 3079-3085. [CrossRef]

144. Suriyakumar, S.; Gopi, S.; Kathiresan, M.; Bose, S.; Gowd, E.B.; Nair, J.R.; Angulakshmi, N.; Meligrana, G.; Bella, F.; Gerbaldi, C.; et al. Metal organic framework laden poly(ethylene oxide) based composite electrolytes for all-solid-state Li-S and Li-metal polymer batteries. Electrochim. Acta 2018, 285, 355-364. [CrossRef]

145. Scalia, A.; Bella, F.; Lamberti, A.; Gerbaldi, C.; Tresso, E. Innovative multipolymer electrolyte mem-brane designed by oxygen inhibited UV-crosslinking enables solid-state in plane integration of energy conversion and storage devices. Energy 2019, 166, 789-795. [CrossRef]

146. Matsui, M. Study on electrochemically deposited Mg metal. J. Power Sources 2011, 196, 7048-7055. [CrossRef]

147. Champagne, P.-L.; Ester, D.F.; Bhattacharya, A.; Hofstetter, K.; Zellman, C.; Bag, S.; Yu, H.; Trudel, S.; Michaelis, V.K.; Williams, V.E.; et al. Liquid crystalline lithium-ion electrolytes derived from biodegradable cyclodextrin. J. Mater. Chem. A 2019, 7, 12201-12213. [CrossRef]

148. Luo, G.; Yuan, B.; Guan, T.; Cheng, F.; Zhang, W.; Chen, J. Synthesis of Single Lithium-Ion Conducting Polymer Electrolyte Membrane for Solid-State Lithium Metal Batteries. ACS Appl. Energy Mater. 2019, 2, 3028-3034. [CrossRef]

149. Long, M.-C.; Xia, L.-T.; Lyu, T.-B.; Wang, T.; Huang, T.; Chen, L.; Wu, G.; Wang, X.-L.; Wang, Y.-Z. A green and facile way to prepare methylcellulose-based porous polymer electrolytes with high lithium-ion conductivity. Polymer 2019, 176, 256-263. [CrossRef]

150. Liu, Y.; Zhu, Y.; Cui, Y. Challenges and opportunities towards fast-charging battery materials. Nat. Energy 2019, 4, 540-550. [CrossRef]

151. Zhang, M.; Yu, S.; Mai, Y.; Zhang, S.; Zhou, Y. A single-ion conducting hyperbranched polymer as a high performance solid-state electrolyte for lithium ion batteries. Chem. Commun. 2019, 55, 6715-6718. [CrossRef]

152. Attias, R.; Salama, M.; Hirsch, B.; Gofer, Y.; Aurbach, D. Solvent Effects on the Reversible Intercalation of Magnesium-Ions into V2 O5 Electrodes. ChemElectroChem 2018, 5, 3514-3524. [CrossRef]

153. Kamphaus, E.P.; Balbuena, P.B. Effects of Dimethyl Disulfide Cosolvent on Li-S Battery Chemistry and Performance. Chem. Mater. 2019, 31, 2377-2389. [CrossRef]

154. Betz, J.; Brinkmann, J.P.; Nölle, R.; Lürenbaum, C.; Kolek, M.; Stan, M.C.; Winter, M.; Placke, T. Cross talk between transition metal cathode and Li metal anode: Unraveling its influence on the deposition/dissolution behavior and morphology of lithium. Adv. Energy Mater. 2019, 9, 1900574. [CrossRef]

155. Lopez, J.; Mackanic, D.G.; Cui, Y.; Bao, Z. Designing polymers for advanced battery chemistries. Nat. Rev. Mater. 2019, 4, 312-330. [CrossRef]

156. Gunday, S.T.; Kamal, A.Z.; Almessiere, M.A.; Çelik, S.Ü.; Bozkurt, A. An investigation of lithium ion conductivity of copolymers based on P(AMPS-co-PEGMA). J. Appl. Polym. Sci. 2019, 136, 47798. [CrossRef]

157. Ganesan, V. Ion transport in polymeric ionic liquids: Recent developments and open questions. Mol. Syst. Des. Eng. 2019, 4, 280-293. [CrossRef]

158. Arthur, T.S.; Singh, N.; Matsui, M. Electrodeposited Bi, Sb and Bi1-xSbx alloys as anodes for Mg-ion batteries. Electrochem. Commun. 2012, 16, 103-106. [CrossRef]

159. Di Leo, R.A.; Zhang, Q.; Marschilok, A.C.; Takeuchi, K.J.; Takeuchi, E.S. Composite anodes for sec-ondary magnesium ion batteries prepared via electrodeposition of nanostructured bismuth on carbon nanotube substrates. ECS Electrochem. Lett. 2015, 4, A10-A14. [CrossRef]

160. Barnes, A.C.; Guo, C.; Howells, W.S. Fast-ion conduction and the structure of beta -Mg3Bi2. J. Physics: Condens. Matter 1994, 6, L467-L471. [CrossRef]

161. Shao, Y.; Gu, M.; Li, X.; Nie, Z.; Zuo, P.; Li, G.; Liu, T.; Xiao, J.; Cheng, Y.; Wang, C.; et al. Highly Reversible Mg Insertion in Nanostructured Bi for Mg Ion Batteries. Nano Lett. 2014, 14, 255-260. [CrossRef]

162. Murgia, F.; Stievano, L.; Monconduit, L.; Berthelot, R. Insight into the electrochemical behavior of micrometric Bi and Mg3Bi2 as high performance negative electrodes for Mg batteries. J. Mater. Chem. A 2015, 3, 16478-16485. [CrossRef] 
163. Vestfried, Y.; Chusid, O.; Goffer, Y.; Aped, P.; Aurbach, D. Structural Analysis of Electrolyte Solutions Comprising Magnesium-Aluminate Chloro-Organic Complexes by Raman Spectroscopy. Organometallics 2007, 26, 3130-3137. [CrossRef]

164. Jin, W.; Li, Z.; Wang, Z.; Fu, Y.Q. Mg ion dynamics in anode materials of Sn and Bi for Mg-ion bat-teries. Mater. Chem. Phys. 2016, 182, 167-172. [CrossRef]

165. Singh, N.; Arthur, T.S.; Ling, C.; Matsui, M.; Mizuno, F. A high energy-density tin anode for re-chargeable magnesium-ion batteries. Chem. Commun. 2013, 49, 149-151. [CrossRef]

166. Parent, L.R.; Cheng, Y.; Sushko, P.V.; Shao, Y.; Liu, J.; Wang, C.-M.; Browning, N.D. Realizing the Full Potential of Insertion Anodes for Mg-Ion Batteries Through the Nanostructuring of Sn. Nano Lett. 2015, 15, 1177-1182. [CrossRef]

167. Cheng, Y.; Shao, Y.; Parent, L.R.; Sushko, M.L.; Li, G.; Sushko, P.V.; Browning, N.D.; Wang, C.; Liu, J. Interface Promoted Reversible Mg Insertion in Nanostructured Tin-Antimony Alloys. Adv. Mater. 2015, 27, 6598-6605. [CrossRef]

168. Wang, Z.; Su, Q.; Shi, J.; Deng, H.; Yin, G.Q.; Guan, J.; Wu, M.P.; Zhou, Y.L.; Lou, H.L.; Fu, Y.Q. Comparison of Tetragonal and Cubic Tin as Anode for Mg Ion Batteries. ACS Appl. Mater. Interfaces 2014, 6, 6786-6789. [CrossRef] [PubMed]

169. Nguyen, D.-T.; Tran, X.M.; Kang, J.; Song, S.-W. Magnesium Storage Performance and Surface Film Formation Behavior of Tin Anode Material. ChemElectroChem 2016, 3, 1813-1819. [CrossRef]

170. Niu, J.; Gao, H.; Ma, W.; Luo, F.; Yin, K.; Peng, Z.; Zhang, Z. Dual phase enhanced superior electro-chemical performance of nanoporous bismuth-tin alloy anodes for magnesium-ion batteries. Energy Storage Mater. 2018, 14, 351-360. [CrossRef]

171. Massaro, A.; Muñoz-García, A.B.; Maddalena, P.; Bella, F.; Meligrana, G.; Gerbaldi, C.; Pavone, M. First-principles study of Na insertion at TiO2 anatase surfaces: New hints for Na-ion battery design. Nanoscale Adv. 2020, 2, 2745-2751. [CrossRef]

172. Bella, F.; Muñoz-García, A.B.; Colò, F.; Meligrana, G.; Lamberti, A.; Destro, M.; Pavone, M.; Gerbaldi, C. Combined structural, chemometric, and electrochemical investigation of vertically aligned TiO2 nano-tubes for Na-ion batteries. ACS Omega 2018, 3 , 8440-8450. [CrossRef]

173. Thimmappa, R.; Gautam, M.; Aralekallu, S.; Devendrachar, M.I.C.; Kottaichamy, A.R.; Bhat, Z.M.; Thotiyl, M.O. A Rechargeable Aqueous Sodium-Ion Battery. ChemElectroChem 2019, 6, 2095-2099. [CrossRef]

174. Zheng, J.; Liu, X.; Duan, Y.; Chen, L.; Zhang, X.; Feng, X.; Chen, W.; Zhao, Y. Stable cross-linked gel terpolymer electrolyte containing methyl phosphonate for sodium ion batteries. J. Membr. Sci. 2019, 583, 163-170. [CrossRef]

175. Wang, P.; Zhang, H.; Chai, J.; Liu, T.; Hu, R.; Zhang, Z.; Li, G.; Cui, G. A novel single-ion conducting gel polymer electrolyte based on polymeric sodium tartaric acid borate for elevated-temperature sodium metal batteries. Solid State Ionics 2019, 337, 140-146. [CrossRef]

176. Luo, L.; Zhen, Y.; Lu, Y.; Zhou, K.; Huang, J.; Huang, Z.; Mathur, S.; Hong, Z. Structural evolution from layered Na2Ti3O7 to Na2Ti6O13 nanowires enabling a highly reversible anode for Mg-ion batteries. Nanoscale 2020, 12, 230-238. [CrossRef]

177. Yang, R.; Zhang, F.; Lei, X.; Zheng, Y.; Zhao, G.; Tang, Y.; Lee, C.S. Pseudocapacitive Ti-doped ni-obium pentoxide nanoflake structure design for a fast kinetics anode toward a high-performance Mg-ion-based dual-ion battery. ACS Appl. Mater. Interfaces 2020, 12, 47539-47547. [CrossRef]

178. Imperiyka, M.; Ahmad, A.; Hanifah, S.A.; Bella, F. A UV-prepared linear polymer electrolyte mem-brane for dye-sensitized solar cells. Physica B 2014, 450, 151-154. [CrossRef]

179. Sacco, A.; Bella, F.; De La Pierre, S.; Castellino, M.; Bianco, S.; Bongiovanni, R.; Pirri, C.F. Elec-trodes/electrolyte interfaces in the presence of a surface-modified photopolymer electrolyte: Application in dye-sensitized solar cells. ChemPhysChem 2015, 16, 960-969. [CrossRef]

180. Bella, F.; Galliano, S.; Piana, G.; Giacona, G.; Viscardi, G.; Grätzel, M.; Barolo, C.; Gerbaldi, C. Boosting the efficiency of aqueous solar cells: A photoelectrochemical estimation on the effectiveness of TiCl4 treatment. Electrochimica Acta 2019, 302, 31-37. [CrossRef]

181. Bella, F.; Sacco, A.; Massaglia, G.; Chiodoni, A.; Pirri, C.F.; Quaglio, M. Dispelling clichés at the nanoscale: The true effect of polymer electrolytes on the performance of dye-sensitized solar cells. Nanoscale 2015, 7, 12010-12017. [CrossRef]

182. Bella, F.; Chiappone, A.; Nair, J.R.; Meligrana, G.; Gerbaldi, C. Effect of different green cellulosic matrices on the performance of polymeric dye-sensitized solar cells. Chem. Eng. Trans. 2014, 41, 211-216.

183. Zhang, H.; Cao, D.; Bai, X. High rate performance of aqueous magnesium-ion batteries based on the $\delta$-MnO2@carbon molecular sieves composite as the cathode and nanowire VO2 as the anode. J. Power Sources 2019, 444, 227299. [CrossRef]

184. Shakerzadeh, E.; Kazemimoghadam, F. Magnesiation of bare and halides encapsulated B40 fullerenes for their potential application as promising anode materials for Mg-ion batteries. Appl. Surf. Sci. 2021, 538, 148060. [CrossRef]

185. Wu, D.; Yang, B.; Chen, H.; Ruckenstein, E. Mechanical deformation induced charge redistribution to promote the high performance of stretchable magnesium-ion batteries based on two-dimensional C2N an-odes. Nanoscale 2019, 11, 15472-15478. [CrossRef] [PubMed]

186. Murgia, F.; Weldekidan, E.T.; Stievano, L.; Monconduit, L.; Berthelot, R. First investigation of in-dium-based electrode in Mg battery. Electrochem. Commun. 2015, 60, 56-59. [CrossRef]

187. Blondeau, L.; Surblé, S.; Foy, E.; Khodja, H.; Gauthier, M. Electrochemical reactivity of In-Pb solid solution as a negative electrode for rechargeable Mg-ion batteries. J. Energy Chem. 2021, 55, 124-128. [CrossRef]

188. Periyapperuma, K.; Tran, T.T.; Purcell, M.; Obrovac, M. The Reversible Magnesiation of Pb. Electrochim. Acta 2015, 165, 162-165. [CrossRef] 
189. Bella, F.; Pugliese, D.; Nair, J.R.; Sacco, A.; Bianco, S.; Gerbaldi, C.; Barolo, C.; Bongiovanni, R. A UV-crosslinked polymer electrolyte membrane for quasi-solid dye-sensitized solar cells with excellent ef-ficiency and durability. Phys. Chem. Chem. Phys. 2013, 15, 3706-3711. [CrossRef]

190. Bella, F.; Imperiyka, M.; Ahmad, A. Photochemically produced quasi-linear copolymers for stable and efficient electrolytes in dye-sensitized solar cells. J. Photochem. Photobiol. A: Chem. 2014, 289, 73-80. [CrossRef]

191. Bella, F.; Vlachopoulos, N.; Nonomura, K.; Zakeeruddin, S.M.; Grätzel, M.; Gerbaldi, C.; Hagfeldt, A. Direct light-induced polymerization of cobalt-based redox shuttles: An ultrafast way towards stable dye-sensitized solar cells. Chem. Commun. 2015, 51, 16308-16311. [CrossRef]

192. Bella, F.; Lamberti, A.; Bianco, S.; Tresso, E.; Gerbaldi, C.; Pirri, C.F. Floating, flexible polymeric dye-sensitized solar-cell architecture: The way of near-future photovoltaics. Adv. Mater. Technol. 2016, 1, 1600002. [CrossRef] 